\title{
GLL
}

Geomatics, Landmanagement and Landscape No. 3 • 2021, 93-122

\section{ENERGY CLUSTER - AN ATTEMPT IN CHARACTERISATION AND DEFINITION}

\author{
Joanna Gronkowska
}

\section{Summary}

Clusters are an organisational and economic phenomenon. This paper attempts to answer what an energy cluster actually is and whether it meets the requirements of a cluster in the classical approach of economic sciences.

The Act of 20 February 2015 on renewable energy sources (Ustawa OZE 2015) introduced the concept of an 'energy cluster'. It was aimed at, among others, increasing energy security and environmental protection through an efficient use of renewable energy sources. In the literature on the subject, there is no single universally applicable definition of a cluster, it can only be considered in its various aspects. The concept of a cluster has so many applications, associations and meanings that in many respects it has become a 'chaotic idea' due to flattening and equalising different types, processes and spatial scales of economic location within one universal concept. However, the main doubt concerns the very definition of a cluster.

The paper considers the organisational attributes of clusters, based on the analysis of the following aspects:

a) Cluster in historical terms. Overview of cluster and network definitions:

i. Overview of cluster definitions

ii. Overview of network structure definitions

b) Energy cluster. Forms of interorganisational relations and the typology of energy clusters

i. Forms of interorganisational relations in an energy cluster

ii. Energy cluster against in relation to organisational network typology

iii. Energy cluster as a form of company network - common features and differences

c) An attempt in characterisation and definition of an energy cluster

\section{Keywords}

energy cluster $\bullet$ network structure $\bullet$ cooperation $\bullet$ business alliance

\section{Introduction}

Clusters are an organisational and economic phenomenon and, as J. Kaźmierski has noted, their functioning has already been observed in many countries around the world [Kaźmierski 2012, p. 9]. They are created in virtually all sectors of the economy, such as industry, services, high-tech. 
This paper attempts to answer what an energy cluster actually is and whether it meets the requirements of a cluster in the classical approach of economic sciences. The Act of 20 February 2015 on renewable energy sources [Ustawa OZE 2015] introduced the concept of an 'energy cluster' as a civil law agreement, which may include natural persons, legal persons, scientific units, research institutes or local government units, regarding the generation and balancing of demand, distribution or trading of energy from renewable energy sources or from other sources or fuels, within a distribution network with a rated voltage lower than $110 \mathrm{kV}$, in the area of operation of this cluster not exceeding the boundaries of one poviat within the meaning of the Act of 5 June 1998 on poviat self-government (Dz.U. 2016 poz. 814) or 5 municipalities within the meaning of the Act of 8 March 1990 on municipal self-government (Dz.U. 2016 poz. 814); the energy cluster is represented by a coordinator who is a cooperative, association, foundation or any member of the energy cluster designated in the civil law agreement, hereinafter referred to as the 'energy cluster coordinator'.

According to M.E. Porter's definition, a cluster is a geographical concentration of interconnected enterprises, specialized suppliers, service providers, enterprises operating in related sectors and associated institutions in particular fields, competing with each other, but also cooperating [Porter 1998, p. 200, Porter 2000, p. 15-34, Pilarska 2013, p. 19].

The analysis of the literature on the subject allows to conclude that a cluster is a kind of network with five permanent distinctive features, which must occur simultaneously [Skawińska and Zalewski 2009, p. 173, Barczak 2016, p. 195]:

- spatial concentration of entities competing with each other in a region,

- concentration of companies within one or several similar sectors,

- informal and formal cooperation of enterprises, local institutions and organizations of a horizontal and vertical nature,

- specialization of entities in a cluster,

- flow of knowledge, technology and innovation between entities of a cluster.

Additional features:

- involvement of entities representing enterprises, research organizations and administration,

- high level of interaction between the entities involved,

- network openness and durable nature,

- rather well-defined network boundaries,

- coopetition as the dominant nature of the relationship,

- achieving external benefits as a whole and benefits for individual cluster members,

- formalized cooperation of entities,

- designated entity acting as a coordinator,

- openness to cooperation, for example with academia. 
In the above list of features, a term 'coopetition' appears meaning a type of relationship between competitors that simultaneously compete and cooperate with each other [Cygler 2007, p. 61, Skawińska and Zalewski 2009, p. 171]. So, if there is no mention of competition in the definition in the act on renewable energy sources, the question remains: what is an energy cluster? In search of an answer to this question, the desk research method was applied, based on the study of source documentation and information contained in foreign and Polish scientific publications.

\section{Cluster in historical terms. Overview of cluster and network definitions}

According to E. Skawińska and R.I. Zalewski [Skawińska and Zalewski 2009, p. 19-21], the oldest example of a cluster described in the literature comes from the period 4000$3500 \mathrm{BC}$ in the area of today's southern Iraq. In this area, there were special spheres for strictly defined types of crafts and specialized markets, with developed legal rules, management methods, production and exchange of goods and services. It is believed that the theoretical roots of the conception of cluster can be traced back to the $18^{\text {th }}$ century in the works of the father of modern economics, Adam Smith. According to Smith, the choice of one industry as the dominant industry in a given country allowed to increase the amount of produced goods. It is believed that the first to use the term 'industrial districts', which is often interchangeably applied with the word 'cluster', was William E. Hearn, in whose name the term appears as early as 1863 . On the other hand, Alfred Marshall is said to be the founder of the theory of clusters. In his work, the Principles of Economics, published in 1890, he stressed the importance of the benefits that can be achieved thanks to the 'concentration of many small companies of a similar nature in one town, in other words, thanks to the industry location' [Marshall 1925, p. 258, Pilarska 2013, p. 10].

The notion of the industrial district as a socially, economically and territorially separated unit, characterized by the active presence of both the community and specialized companies operating in naturally and historically limited areas, gained a 'new life' later, when economists became interested in the path of industrial development pursued in certain regions of Italy known as 'third Italy'. This region went through a rapid development in the 1970s, especially its small and medium industrial companies, and was related primarily to the strong concentration of these companies in specific sectors and locations. The main features of these districts were determined, such as: geographical proximity, sector specialization, domination (advantage) of small and medium-sized enterprises, close cooperation, but also competition between companies, striving for innovation, socio-cultural identity (uniformity) in favour of building trust, active support authorities at both local and regional level [Becattini 1991, p. 86, Hamphrey and Schmitz 1995, p. 2-3, Bellandi 2007, p. 7, Pilarska 2013, p. 14-16].

In conclusion, geographic, specialized clusters of related economic entities have functioned in the economy for centuries, but only since the M.E. Porter's work in 1990 (The Competitive Advantage of Nations) the term 'clusters' became popular [Skawińska and Zalewski 2009, p. 19]. 
'There is no single universally applicable definition of a cluster... it is only considered in its various aspects' in the literature on the subject [Jacobs and de Man 1996, p. 425]. This is very well described by R. Martin and P. Sunley, who claim that '(...) the notion of a cluster has so many applications, associations and meanings that in many respects it has become a «chaotic idea» due to flattening and equalizing different types, processes and spatial scales of economic location within one universal concept', however, '(...) the main doubt concerns the very definition of a cluster' [Lis and Lis 2014 , p. 21, Martin and Sunley 2003, p. 10]. The above statements are illustrated by the cluster definitions presented in Table 1.

Table 1. Overview of cluster definitions

\begin{tabular}{|c|c|c|c|}
\hline No. & Year & Author & Network definition \\
\hline 1 & 1992 / 1996 & M. Enright & $\begin{array}{l}\text { A set of related enterprises, representing the same or a similar } \\
\text { industry or service sector, located in the same area (geographical } \\
\text { proximity). Concentration of economic entities in a close prox- } \\
\text { imity }\end{array}$ \\
\hline 2 & 1995 & R. Rabelotti & $\begin{array}{l}\text { A grouping of spatially concentrated and enterprises specialised } \\
\text { to a sector (mainly small and medium-sized) with links based } \\
\text { on market and non-market exchanges of goods, information and } \\
\text { labour, which are connected by a common culture and social ori- } \\
\text { gin (translated into a specific code of behaviour), supported by } \\
\text { a network of public and private local institutions }\end{array}$ \\
\hline 3 & 1996 & C. DeBresson & $\begin{array}{l}\text { Innovative clusters are not a mere concentration of independent } \\
\text { business entities, but networks of interconnected, cooperating } \\
\text { enterprises at an industry level }\end{array}$ \\
\hline 4 & 1996 / 1998 & $\begin{array}{l}\text { P. Swann, } \\
\text { M. Prevezer }\end{array}$ & $\begin{array}{l}\text { Groups of enterprises that work together within one sector in } \\
\text { a specific geographic area. Clusters are defined as groups of com- } \\
\text { panies within one industry sector located in one geographic area. } \\
\text { A cluster means a large group of companies from related sectors } \\
\text { in a specific location }\end{array}$ \\
\hline 5 & 1996 / 1997 & S. Rosenfeld & $\begin{array}{l}\text { Geographically concentrated, similar, related or complemen- } \\
\text { tary enterprises with active channels for business transactions, } \\
\text { communication and dialogue, having access to specialised infra- } \\
\text { structure, labour market and services, facing the same opportu- } \\
\text { nities and threats. It is a system of which membership is based } \\
\text { on mutual dependence and contribution to the functioning of } \\
\text { this system. Clusters of companies which have the opportunity to } \\
\text { create synergy effects through geographical proximity and close } \\
\text { cooperation, regardless of the scale of employment }\end{array}$ \\
\hline 6 & 1997 & $\begin{array}{l}\text { B.A. Lundvall, } \\
\text { S. Borras }\end{array}$ & $\begin{array}{l}\text { The region where innovations are delivered by regional networks } \\
\text { of innovative entities and local clusters as a result of cooperation } \\
\text { with research institutions will be at a higher level of development }\end{array}$ \\
\hline 7 & 1998 & E.J. Feser & $\begin{array}{l}\text { Clusters are not so much related and cooperating entities, but } \\
\text { rather related and supporting institutions that gain a competitive } \\
\text { advantage through a network of connections }\end{array}$ \\
\hline
\end{tabular}




\begin{tabular}{|c|c|c|c|}
\hline 8 & 1998 & $\begin{array}{l}\text { T. Padmore, } \\
\text { H. Gibson }\end{array}$ & $\begin{array}{l}\text { Concentration of enterprises in a definite area, whose economic } \\
\text { success is determined by their interactions and facilitated by geo- } \\
\text { graphical proximity }\end{array}$ \\
\hline 9 & $1998 / 2001$ & M.E. Porter & $\begin{array}{l}\text { Geographical cluster of interconnected companies, specialized } \\
\text { suppliers, service providers, companies operating in related sec- } \\
\text { tors and related institutions in particular fields, competing with } \\
\text { each other, but also cooperating. A group of enterprises and co- } \\
\text { operating institutions related to and complementing each other. } \\
\text { A cluster is a group of geographically closely interrelated compa- } \\
\text { nies and related institutions in a given field, connected by simi- } \\
\text { larities and complementarity }\end{array}$ \\
\hline 10 & 1998 & $\begin{array}{l}\text { P. Swann, } \\
\text { M. Prevezer }\end{array}$ & $\begin{array}{l}\text { A large group of companies from similar sectors concentrated in } \\
\text { one geographical area and cooperating with each other }\end{array}$ \\
\hline 11 & 1999 & $\begin{array}{l}\text { J. Simmie, } \\
\text { J. Sennert }\end{array}$ & $\begin{array}{l}\text { Highly related enterprises and/or service sector companies coop- } \\
\text { erating within the supply chain and respecting the same market } \\
\text { principles }\end{array}$ \\
\hline 12 & 1999 & $\begin{array}{l}\text { T. Roelandt, } \\
\text { P. den Hertog }\end{array}$ & $\begin{array}{l}\text { Supplier networks and closely connected companies that create } \\
\text { added value within a supply chain }\end{array}$ \\
\hline 13 & 1999 & I.W. Munnich & $\begin{array}{l}\text { The cluster is first of all a strategy of economic development } \\
\text { which ensures economic growth in a coordinated and effective } \\
\text { manner }\end{array}$ \\
\hline 14 & 1999 & UNIDO & $\begin{array}{l}\text { Sectoral and geographic concentration of companies that pro- } \\
\text { duce and sell a range of related and complementary products, } \\
\text { therefore facing common challenges and opportunities }\end{array}$ \\
\hline 15 & 2001 & $\begin{array}{l}\text { C. Crouch, } \\
\text { H. Farrell }\end{array}$ & $\begin{array}{l}\text { The tendency of locating enterprises in close proximity to enter- } \\
\text { prises with a similar business profile, despite being previously } \\
\text { absent in a given area }\end{array}$ \\
\hline 16 & 2001 & $\begin{array}{l}\text { L. van den Berg, } \\
\text { E. Braun, } \\
\text { W. van Winden }\end{array}$ & $\begin{array}{l}\text { In most definitions, clusters are defined as localized networks of } \\
\text { specialized entities, which are closely related to each other in the } \\
\text { production process through the exchange of goods, services and/ } \\
\text { or knowledge }\end{array}$ \\
\hline 17 & 2002 & P. Cooke & $\begin{array}{l}\text { Companies cooperate and compete with each other within a spe- } \\
\text { cific market segment, use common local infrastructure and iden- } \\
\text { tify with the same vision of industry and region development } \\
\text { form a geographical cluster with horizontal and vertical links. }\end{array}$ \\
\hline 18 & 2002 & $\begin{array}{l}\text { B. Asheim, } \\
\text { A. Isaksen }\end{array}$ & $\begin{array}{l}\text { The strength of the arguments in favour of regionalisation stems } \\
\text { from the fact that regional level of operations and specific local } \\
\text { and regional resources are still important for companies, es- } \\
\text { pecially when they make efforts to become competitive on the } \\
\text { global market (...). Companies in clusters, when searching for } \\
\text { innovations, rely on unique regional and local resources and mu- } \\
\text { tual cooperation }\end{array}$ \\
\hline 19 & 2002 & $\begin{array}{l}\text { T. Brodzicki, } \\
\text { S. Szultka }\end{array}$ & $\begin{array}{l}\text { A spatially concentrated cluster of enterprises simultaneously } \\
\text { competing and cooperating with each other in certain aspects as } \\
\text { well as institutions and organizations, connected by a system of } \\
\text { mutual relations of formal and informal nature, based on a spe- } \\
\text { cific development trajectory (e.g. technology, sales markets) }\end{array}$ \\
\hline
\end{tabular}


Table 1. cont.

\begin{tabular}{|c|c|c|c|}
\hline No. & Year & Author & Network definition \\
\hline 20 & 2002 & $\begin{array}{l}\text { C. Steinle, } \\
\text { H. Schiele }\end{array}$ & $\begin{array}{l}\text { Clusters are treated as localized sector agglomerations of sym- } \\
\text { biotic organisations that can achieve better business results } \\
\text { through interactions (club-like) }\end{array}$ \\
\hline 21 & 2003 & $\begin{array}{l}\text { European } \\
\text { Commission }\end{array}$ & $\begin{array}{l}\text { Clusters are groups of independent enterprises and related insti- } \\
\text { tutions which: cooperate and compete; are geographically con- } \\
\text { centrated in one or more regions, although a cluster may even } \\
\text { be global in scope; specialize in a specific field, are connected } \\
\text { by common technologies and skills; include modern (science- } \\
\text { based) or traditional industries; can be institutionalised (by } \\
\text { a coordinator) or non-institutionalised. The way of organising } \\
\text { a production system and a territory in which enterprises oper- } \\
\text { ate, characteristic for entities and other organisations that are } \\
\text { geographically concentrated and specialize in the same fields, de- } \\
\text { velop mutual market and non-market relations and contribute to } \\
\text { the innovation and competitiveness of their members }\end{array}$ \\
\hline 22 & 2003 & $\begin{array}{l}\text { M.P.V. van Dijk, } \\
\text { Á. Sverrisson }\end{array}$ & $\begin{array}{l}\text { Clusters are relatively dense networks of companies and organi- } \\
\text { sations whose value chains are interconnected, but not necessar- } \\
\text { ily by what we usually mean by economic transactions }\end{array}$ \\
\hline 23 & 2004 & P. Morosini & $\begin{array}{l}\text { Socio-economic unit characterised by a social community and } \\
\text { a set of economic entities located in close proximity, in a particu- } \\
\text { lar geographic region }\end{array}$ \\
\hline 24 & 2004 & OECD & $\begin{array}{l}\text { Concentration in a given area of related (vertically and / or hori- } \\
\text { zontally) enterprises operating in the same sector (industry or } \\
\text { services) together with related institutions }\end{array}$ \\
\hline 25 & 2005 & $\begin{array}{l}\text { P. Masell, } \\
\text { L. Kebir }\end{array}$ & $\begin{array}{l}\text { Clusters can be defined as non-random geographical agglomera- } \\
\text { tions of companies with similar or closely complementary pro- } \\
\text { duction capacities }\end{array}$ \\
\hline 26 & 2005 & $\begin{array}{l}\text { Statistics Poland } \\
\text { (GUS) }\end{array}$ & $\begin{array}{l}\text { Networks of related enterprises, their suppliers and customers, } \\
\text { scientific and educational institutions, special government agen- } \\
\text { cies and so-called bridging institutions that provide technical and } \\
\text { consulting services, as well as financial and insurance institutions }\end{array}$ \\
\hline 27 & 2005 & PARP & $\begin{array}{l}\text { Spatial concentration of enterprises, institutions, organisations } \\
\text { interconnected by an extensive network of formal and informal } \\
\text { relations, based on a common development trajectory (e.g. tech- } \\
\text { nological, common target markets, marketing strategy, etc.), si- } \\
\text { multaneously competing and cooperating in certain aspects of } \\
\text { operation }\end{array}$ \\
\hline 28 & 2006 & $\begin{array}{l}\text { Ch. Pitelis, } \\
\text { R. Sugden, } \\
\text { J.R. Wilson }\end{array}$ & $\begin{array}{l}\text { A cluster is a concentration of companies with a specific type } \\
\text { of activity, usually located in one geographic dimension, hori- } \\
\text { zontally and (preferably) vertically related and characterised by } \\
\text { a connection between sectors (in the context of object-institu- } \\
\text { tional setting) that cooperate or compete on the local or inter- } \\
\text { national market }\end{array}$ \\
\hline
\end{tabular}




\begin{tabular}{|c|c|c|c|}
\hline 29 & 2006 & $\begin{array}{l}\text { Ministry } \\
\text { of Economy }\end{array}$ & $\begin{array}{l}\text { Spatial and sectoral concentration of entities operating for the } \\
\text { benefit of economic development or entrepreneurship, and at } \\
\text { least ten entrepreneurs conducting business activity in one or } \\
\text { more neighbouring voivodeships, competing and cooperating in } \\
\text { the same or related industries, and connected with an extensive } \\
\text { network of formal and informal relations, whereby the entrepre- } \\
\text { neurs constitute at least half of the entities operating within the } \\
\text { cluster }\end{array}$ \\
\hline 30 & 2009 & Ö. Söllvell & $\begin{array}{l}\text { Clusters are companies dealing not only with the flow of goods } \\
\text { and services, but also focused on creating knowledge, increasing } \\
\text { profits and innovation in the broad sense }\end{array}$ \\
\hline 31 & 2009 & $\begin{array}{l}\text { M. Gorynia, } \\
\text { B. Jankowska }\end{array}$ & $\begin{array}{l}\text { The group of enterprises and other entities (associations, cham- } \\
\text { bers of commerce and industry, scientific institutions, etc.) op- } \\
\text { erating in close proximity, is characterized by an above-average } \\
\text { intensity of various links and relationships, and these relations to } \\
\text { a large extent go beyond typical market relationships (confronta- } \\
\text { tional, competitive). There are advantages of shared location and } \\
\text { cooperation within this group of companies (external economies } \\
\text { of scale, synergy effect, positive externalities, diffusion effect, } \\
\text { etc.). The cluster is 'an island of cooperation in the assessment } \\
\text { of competition'. }\end{array}$ \\
\hline 32 & 2010 & A.M. Kowalski & $\begin{array}{l}\text { An innovative tool to support cooperation between individual } \\
\text { entities in innovative processes, in particular R\&D units, enter- } \\
\text { prises using the results of their works and business environment } \\
\text { institutions supporting the commercialisation of technologies }\end{array}$ \\
\hline 33 & 2013 & L. Knop & $\begin{array}{l}\text { A group of entities coming from various environments: business, } \\
\text { science, local government and civil society, consciously operat- } \\
\text { ing in a specific ecosystem, focused on a specific territory and/or } \\
\text { around an established specialisation }\end{array}$ \\
\hline 34 & 2014 & $\begin{array}{l}\text { A.M. Lis, } \\
\text { A. Lis }\end{array}$ & $\begin{array}{l}\text { Sectoral and geographical concentration of enterprises linked by } \\
\text { trade and non-trade dependencies within a community of values } \\
\text { and goals that binds them to some extent, while cooperating and } \\
\text { competing using the synergy effect }\end{array}$ \\
\hline 35 & 2014 & CLOE & $\begin{array}{l}\text { Groups of interconnected industries, small and medium-sized } \\
\text { enterprises (SMEs) and organisations that increase their compet- } \\
\text { itiveness by interacting with each other. They can be customers, } \\
\text { suppliers, researchers, partners or rivals, concentrated in certain } \\
\text { geographic regions }\end{array}$ \\
\hline 36 & 2016 & PARP & $\begin{array}{l}\text { Geographical cluster of independent entities representing a spe- } \\
\text { cific economic specialisation, cooperating and competing with } \\
\text { each other within the value chain. Cooperation within the cluster } \\
\text { is formalised, it is implemented both vertically and horizontally, } \\
\text { and is aimed at achieving the assumed common goals. The clus- } \\
\text { ter is a source of benefits and creates new value for all types of } \\
\text { entities participating in it, such as enterprises, universities and } \\
\text { other scientific units, business environment institutions, public } \\
\text { administration and other supporting organisations }\end{array}$ \\
\hline
\end{tabular}


Table 1. cont.

\begin{tabular}{|c|c|c|l|}
\hline No. & Year & Author & \multicolumn{1}{c|}{ Network definition } \\
\hline 37 & 2017 & PARP & $\begin{array}{l}\text { A cluster is a geographical concentration of specialised entities, } \\
\text { interconnected by mutual interactions, operating in related or } \\
\text { complementary industries, at the same time cooperating and } \\
\text { competing with each other, including, in particular: enterprises, } \\
\text { research organisations, business environment institutions, public } \\
\text { entities. It is a specific form of production organisation, consist- } \\
\text { ing in the concentration of flexible enterprises running comple- } \\
\text { mentary economic activities in a close proximity. These entities } \\
\text { simultaneously cooperate and compete with each other, they also } \\
\text { have relations with other institutions operating in a given field. } \\
\text { The basis for the creation of the cluster are cooperative relations } \\
\text { between entities, generating the processes of creating specific } \\
\text { knowledge and increasing adaptability }\end{array}$ \\
\hline
\end{tabular}

Source: Author's study based on: Kaźmierski [2012], p. 68; Martin and Sunley [2003]; Rosenfeld [1996], p. 7; Rosenfeld [1997], p. 4, 7; Porter [2000], p. 16; Porter [2001], p. 246; Porter [1998], p. 200; Cegle and Dini [2015]; ETCoI [2015]; Morosini [2004], p. 307; Matusiak [2005], p. 81; Ministerstwo Gospodarki, Dz.U. 06.226.1651, 2006; Gorynia and Jankowska [2009], pp. 274-275; Kowalski [2010]; Lis and Lis [2014], p. 81; Knop [2013], p. 33; Söllvell [2009], p. 15; CLOE [2014]; Pitelis et al. [2006], p. 20; Munnich [1999], p. 10; Feser [1998], p. 26; Van Dijk and Sverrisson [2003], p. 185; Gorynia and Jankowska [2008], p. 100; OECD [2004], pp. 5, 20; EU [2003], pp. 9, 16; Enright [1996], p. 191; Swann and Prevezer [1996], pp. 1, 139; Padmore and Gibson [1998], p. 57; Rabelotti [1995], p. 30; Cooke [2002], Gorynia and Jankowska [2008], p. 35; Maskell and Kebir [2014], p. 1; DeBresson [1996], p. 161; Steinle and Schiele [2002], p. 850; Lundvall and Borras [1997], p. 39; Swann and Prevezer [1998], p. 1; Roelandt and den Hertog [1999], p. 9; Simmie and Sennett [1999], p. 51; Crouch and Farrell [2001], p. 163; Van den Berget et al. [2001], p. 187; Asheim and Isaksen [2002], p. 4; Maskell and Kebir [2005], p. 1; UNIDO [2001], p. 9; Brodzicki and Szultka [2002], p. 46; Gorynia and Jankowska [2007], p. 319; GUS [2005], p. 132; Ministerstwo Gospodarki [2008]; PARP [2017]; PARP [2017a]; Hołub-Iwan and Wielec [2014], p. 9; Drelich-Skulska et al. [2014], p. 24-25; Kazojć [2016], pp. 59-61; Pilarska [2013], pp. 20-24; Lis and Lis [2014].

Thus, there is no doubt that we lack a clear definition of a cluster. According to B. Glăvan, 'the definitional flexibility of the cluster concept completely prevents its operationalisation, making it an ideal tool for politicians' [Glăvan 2008, p. 52; Lis and Lis 2014, p. 39). In the light of the conducted analysis, it seems justified to extend the considerations to business networks.

As already pointed out by G. Becattini [Becattini et al. 2009], Italian industrial districts have evolved towards local integrated manufacturing networks (filière) and thus into broader structures that can be described as cluster-type structures. Despite many common elements, such as spatial concentration, the proximity of entities or the existence of mutual competition and cooperation, they differed from industrial districts basically in that they are more flexible [McDonald and Belussi 2002, p. 15]. Nowadays, they are not limited only to traditional branches of the economy, but are often targeted at sectors that are the carriers of modernity, in which innovative processes take place [Pilarska 2013, pp. 17-18]. Thus, the cluster cooperation models and industrial districts form the basis for considering business networks [Barczak 2016, p. 23; Rosińska 2005a, p. 372). The network approach is used in such areas of research and practice as: strategic management (relations of competition, cooperation and coopetition), logistics 
management (supply and distribution chains), entrepreneurship, knowledge and innovation management or relationship marketing [Barczak 2016, p. 23; Gancarczyk 2012, p. 61).

In papers devoted to network research, there are various definitions of this notion. Common phrases include network organisations [Phillips 2010, p. 533 et seq.; Higgins and Maciariello 2004, p. 203 et seq.), interorganisational network (see e.g.) [Baker and Faulkner 2002, p. 520), and network structure [Mukherjee 2009, p. 23; Sproull and Kiesler 1992, p. 132 et seq.), 'network company' or just 'networks' [Barczak 2016, p. 53]. There are many definitions of network structures due to the different forms of relationships between network participants. The most important of them, taking into account the essence of clusters, are presented in Table 2.

Table 2. Overview of network structure definitions

\begin{tabular}{|c|c|c|c|}
\hline No. & Year & Author & Network definition \\
\hline 1 & 1986 & H.B. Thorelli & $\begin{array}{l}\text { A network is a set of two or more organisations committed to a long- } \\
\text { term relationship }\end{array}$ \\
\hline 2 & 1998 & P. Drucker & $\begin{array}{l}\text { A network of institutions (or their parts), companies, teams and people } \\
\text { located in different places, organised into loosely connected and non- } \\
\text { transparent structures, which share a common goal - working (provid- } \\
\text { ing services or selling products) for the same customer }\end{array}$ \\
\hline 3 & 1998 & $\begin{array}{l}\text { P. Dwojacki, } \\
\text { B. Nogalski }\end{array}$ & $\begin{array}{l}\text { The network as a relatively permanent grouping of autonomous, special- } \\
\text { ised units and enterprises participating in a system of mutual coopera- } \\
\text { tion according to market principles }\end{array}$ \\
\hline 4 & 1999 & J. Sydow & $\begin{array}{l}\text { An organised, polycentric form of economic activity, often strategically } \\
\text { directed by one or several enterprises, seeking to achieve a competitive } \\
\text { advantage. It is expressed in relatively stable, cooperative rather than } \\
\text { competitive relations between legally independent, but economically at } \\
\text { least interdependent enterprises }\end{array}$ \\
\hline & 2001 & Strategor & $\begin{array}{l}\text { The basic components of the network are the so-called Nodes and con- } \\
\text { nections between them, which - translating into practice - means link- } \\
\text { ing elements of various organisations and institutions into various net- } \\
\text { work combinations (depending on the needs), and their number and } \\
\text { nature are determined by the number and type of relations between } \\
\text { the nodes. The relations between the components of the network can } \\
\text { be multilateral and have a different character: bureaucratic - orders, ap- } \\
\text { plicable standards, procedures; economic material and financial transac- } \\
\text { tions; operational - joint action, collective decision making, use of the } \\
\text { same resources; cultural - sharing values, community of opportunities } \\
\text { and threats; informative availability of information sources, exchange } \\
\text { and sharing of information }\end{array}$ \\
\hline 6 & 2002 & M.J. Hatch & $\begin{array}{l}\text { An organization where hierarchical coordination has been replaced by } \\
\text { horizontal relations, formal relations between organisational units have } \\
\text { been changed to links between partners, which are different organisa- } \\
\text { tions, and assets are divided so that the producer of the finite whole is } \\
\text { not any single organisation of the network, but the network as a whole }\end{array}$ \\
\hline
\end{tabular}


Table 1. cont.

\begin{tabular}{|c|c|c|c|}
\hline No. & Year & Author & Network definition \\
\hline 7 & 2004 & $\begin{array}{l}\text { D. Delporte- } \\
\text {-Vermeiren, } \\
\text { P. Vervest, } \\
\text { F. van Heck }\end{array}$ & $\begin{array}{l}\text { The interorganisational network in business can be a set of relations } \\
\text { between the so-called focusing actor and external actors dependent on } \\
\text { them, working together on the implementation of a specific service for } \\
\text { the client }\end{array}$ \\
\hline 8 & 2005 & K. Łobos & $\begin{array}{l}\text { An interorganisational network (network organisation) is 'a set of more } \\
\text { than two independent organizations that are linked with the following } \\
\text { characteristics: - decisions on resources are made not only integrally } \\
\text { by the parties to the transaction (as is the case in the market), but also } \\
\text { collectively by cooperating parties; - the flow of resources between the } \\
\text { cooperating partners is repetitive, not ad hoc; - the mutual expectations } \\
\text { of the cooperating partners cover a further horizon; - the information } \\
\text { available to the cooperating parties is much more extensive than in the } \\
\text { case of market coordination; - the form of coordination between the } \\
\text { cooperating parties is negotiation, and not competition' }\end{array}$ \\
\hline 9 & 2005 & $\begin{array}{l}\text { K. } \\
\text { Perechuda }\end{array}$ & $\begin{array}{l}\text { A set of legally independent business units implementing various under- } \\
\text { takings and projects coordinated by the integrator's company, which has } \\
\text { distinctive (key, basic) competences }\end{array}$ \\
\hline 10 & 2010 & Z. Olesiński & $\begin{array}{l}\text { A system of various groups of organizations, the elements of which are: } \\
\text { enterprises, local government units, state government institutions (they } \\
\text { ensure the implementation of the policy of supporting banks and other } \\
\text { financial institutions needed to finance the operations of enterprises, } \\
\text { business support organisations and research and development institu- } \\
\text { tions) }\end{array}$ \\
\hline 11 & 2012 & $\begin{array}{l}\text { J. Niemczyk, } \\
\text { E. Stańczyk- } \\
\text {-Hugiet, } \\
\text { B. Jasiński }\end{array}$ & $\begin{array}{l}\text { Two concepts of networks: 1) structures describing a specific form of } \\
\text { operation (cooperation) of private and or public entities, 2) forms being } \\
\text { a new structure created by the mentioned entities, which pursue a com- } \\
\text { mon goal }\end{array}$ \\
\hline
\end{tabular}

Source: Author's study based on: Thorelli [1986], p. 37; Drucker [1998]; Dwojacki and Nogalski [1998], p. 69; Sydow [1999], p. 103; Strategor [2001]; Hatch [2002], p. 195; Delporte-Vermeiren et al. [2004]; Łobos [2005], p. 167; Perechuda [2005]; Olesiński [2010], p. 66; Niemczyk et al. [2012], p. 9; Barczak [2016], p. 54-58.

Taking into account the above list, the main distinctive features of a network structure are [Barczak 2016, p. 59, Niemczyk et al. 2012, p. 10]:

- Multilateral relations between network components,

- Diversified nature of network relations (bureaucratic, economic, cultural, information),

- Shared use of resources by network participants,

- Repetitive nature of resource flows between partners,

- Market-based coordination mechanisms,

- Negotiations and agreements as a form of coordination of activities between cooperating parties,

- Striving for cooperation, 
- Autonomy of the units (with a significant scope of coopetition),

- Long-term (strategic) nature of cooperation between network participants,

- Increasing the potential of knowledge and innovation,

- A shared value system,

- Low level of horizontal integration and hierarchy,

- Flexibility,

- Benefits of cooperation (synergy effect).

It can be noticed that in the case of network structures, there is also coopetition, as a special type of relationship between partners with a simultaneous relationship of competition and cooperation. At the same time, however, as in the case of clusters, the concept of networks is still not a fully explored and structured concept. Therefore, it is important to indicate the key attributes of interorganizational relations in the network and to classify them so that relations in the energy cluster can be defined.

\section{Energy cluster. Forms of interorganisational relations and the typology of energy clusters}

The following is an attempt to develop forms of interorganisational relations in an energy cluster against the background of their various characteristics presented in the literature.

The literature on the subject presents a variety of typologies of organisational networks. Table 4 shows an attempt to develop an energy cluster type against their background.

On the basis of the presented analysis, it can be concluded that an energy cluster bases its activity on cooperative relations. There cannot be any competitive relations when a subject of cooperation is taken into account. At this point, it is necessary to return to the definition of coopetition, in terms of the dependencies occurring between entities in the energy cluster, understood as a dyadic and paradoxical relationship between two companies that cooperate within the same operations, and compete within other activities' [Bengtsson and Kock 1999; Wiśniewska and Janasz 2015, p. 184). The common features and differences between the networks of companies, classic cluster and energy cluster are presented in Table 5. 


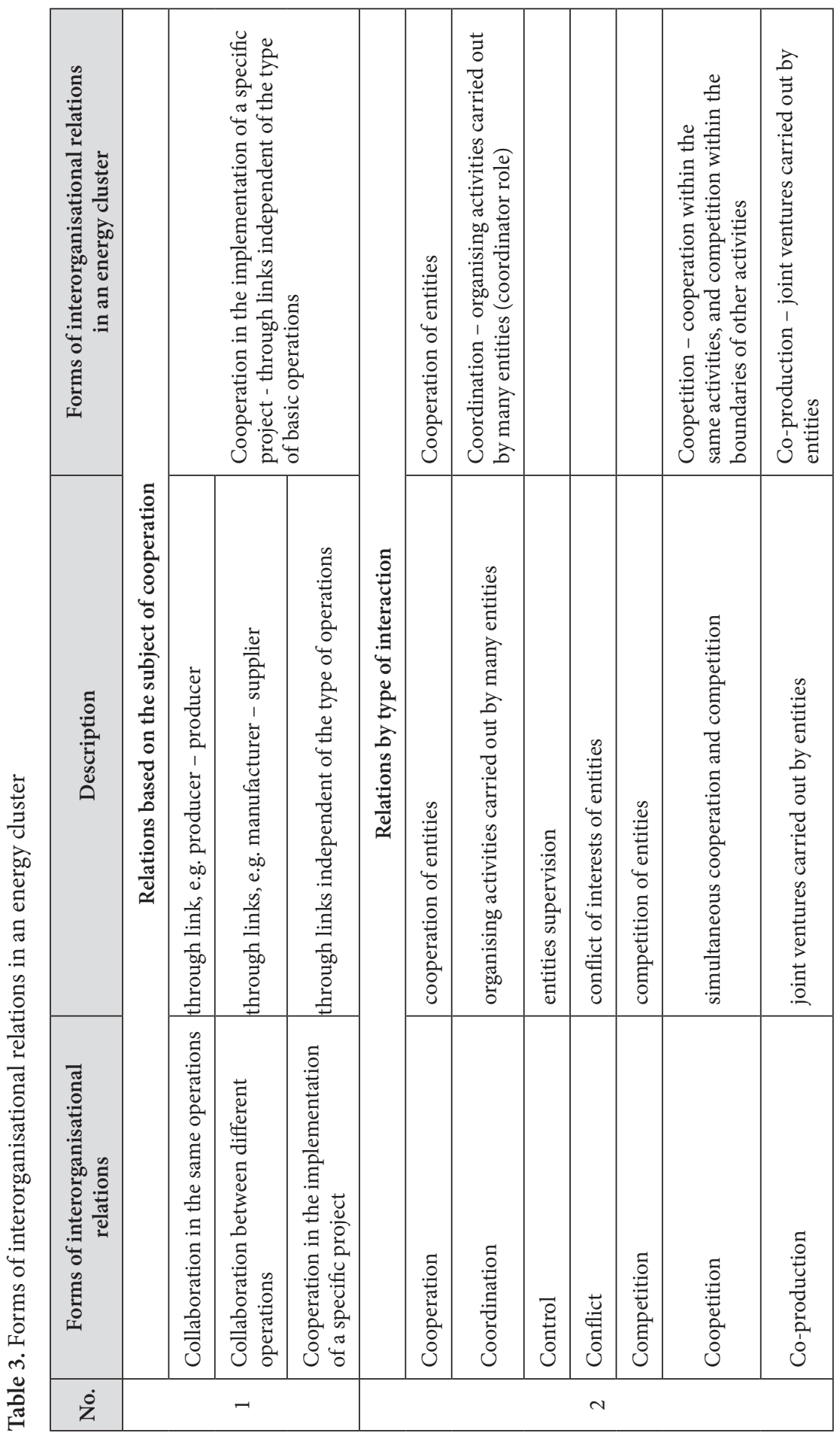




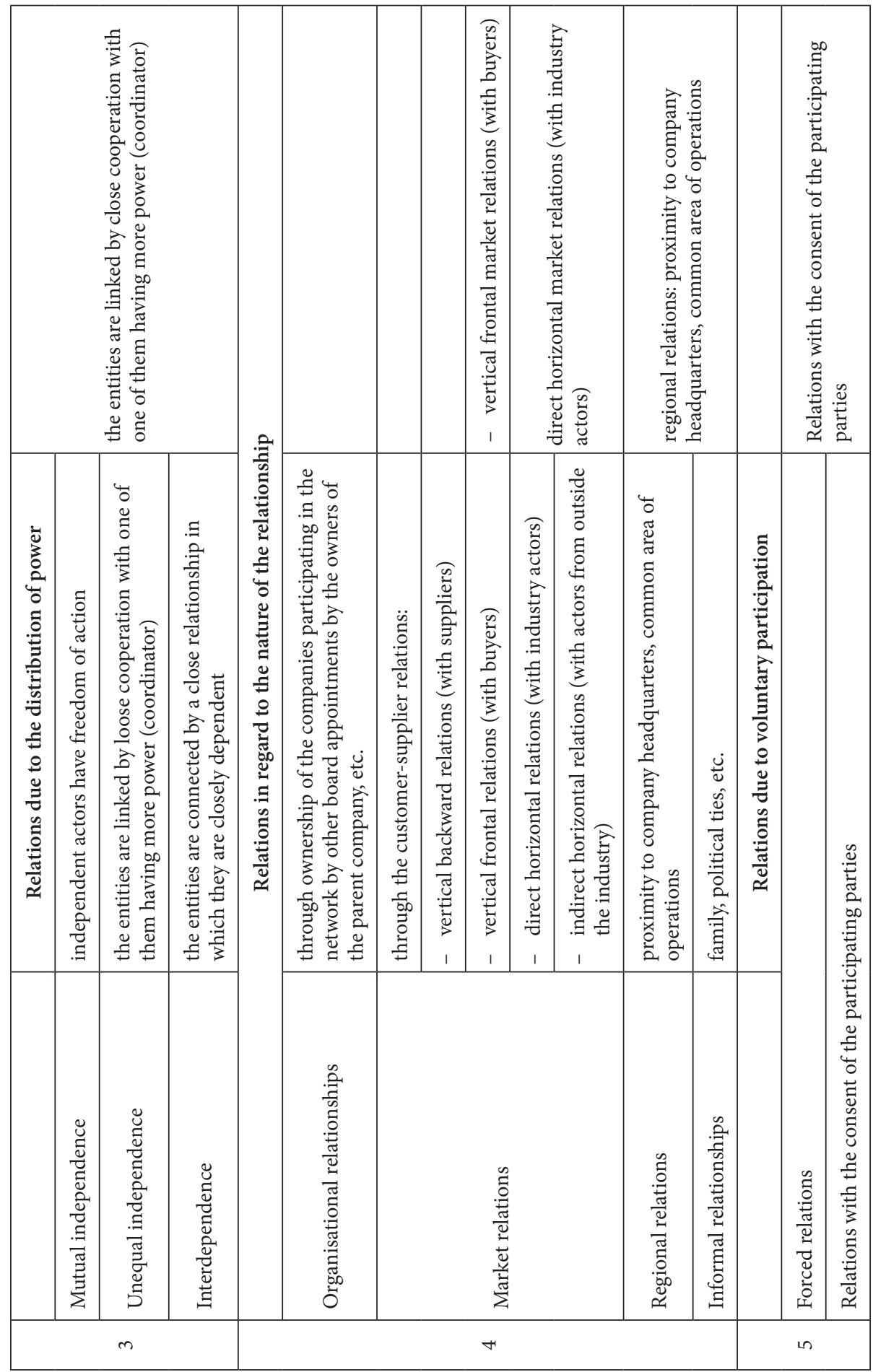




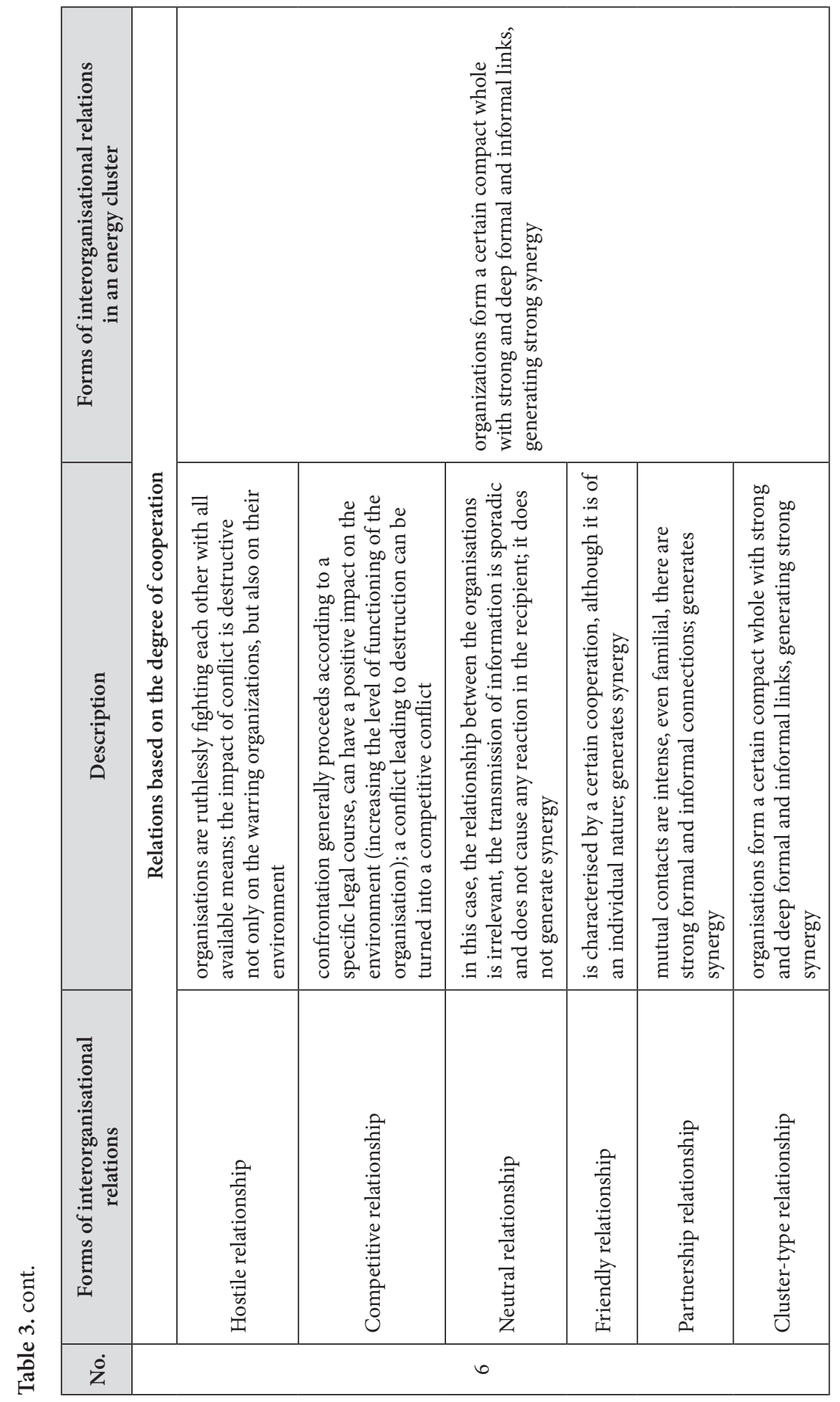




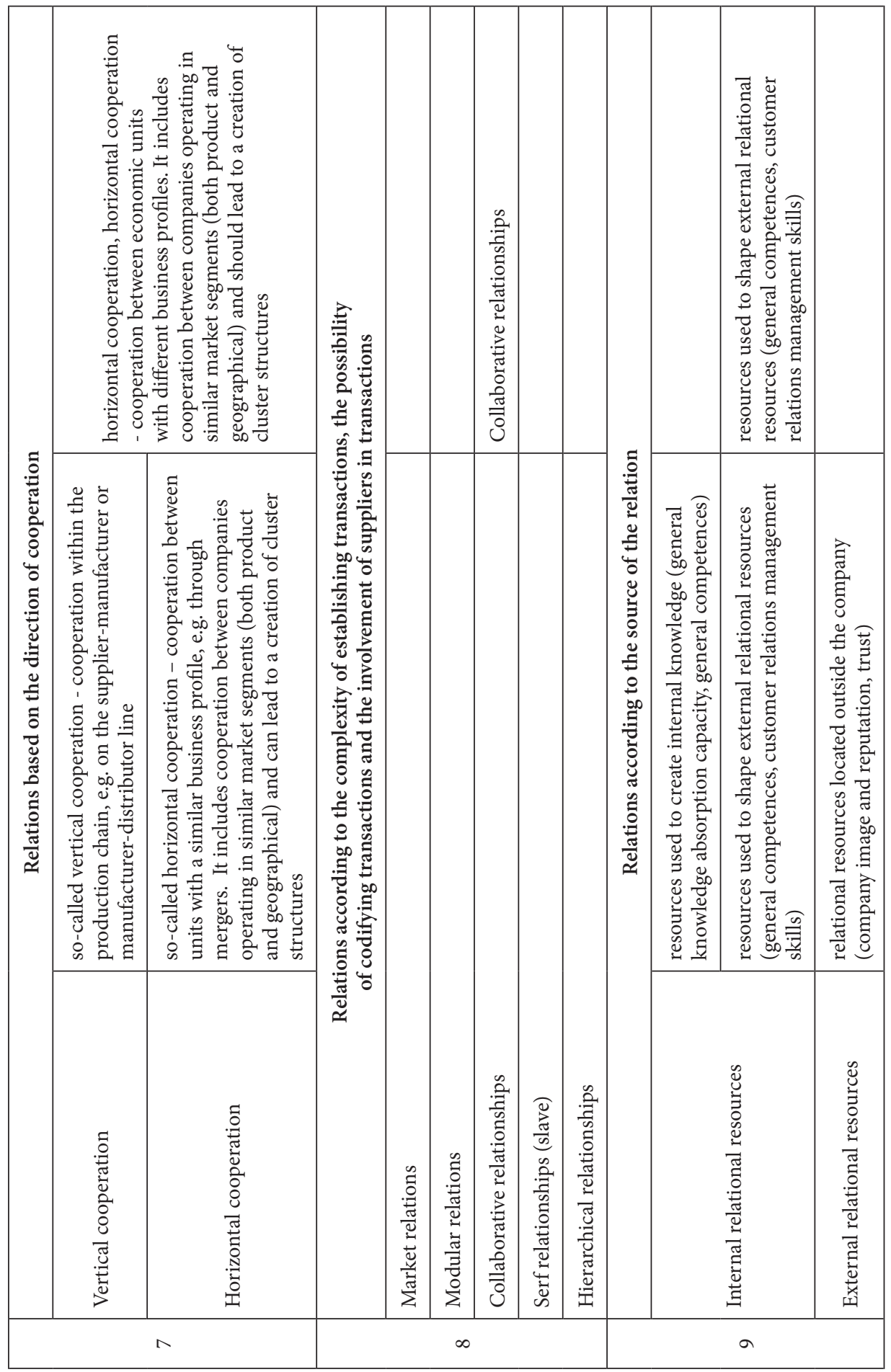




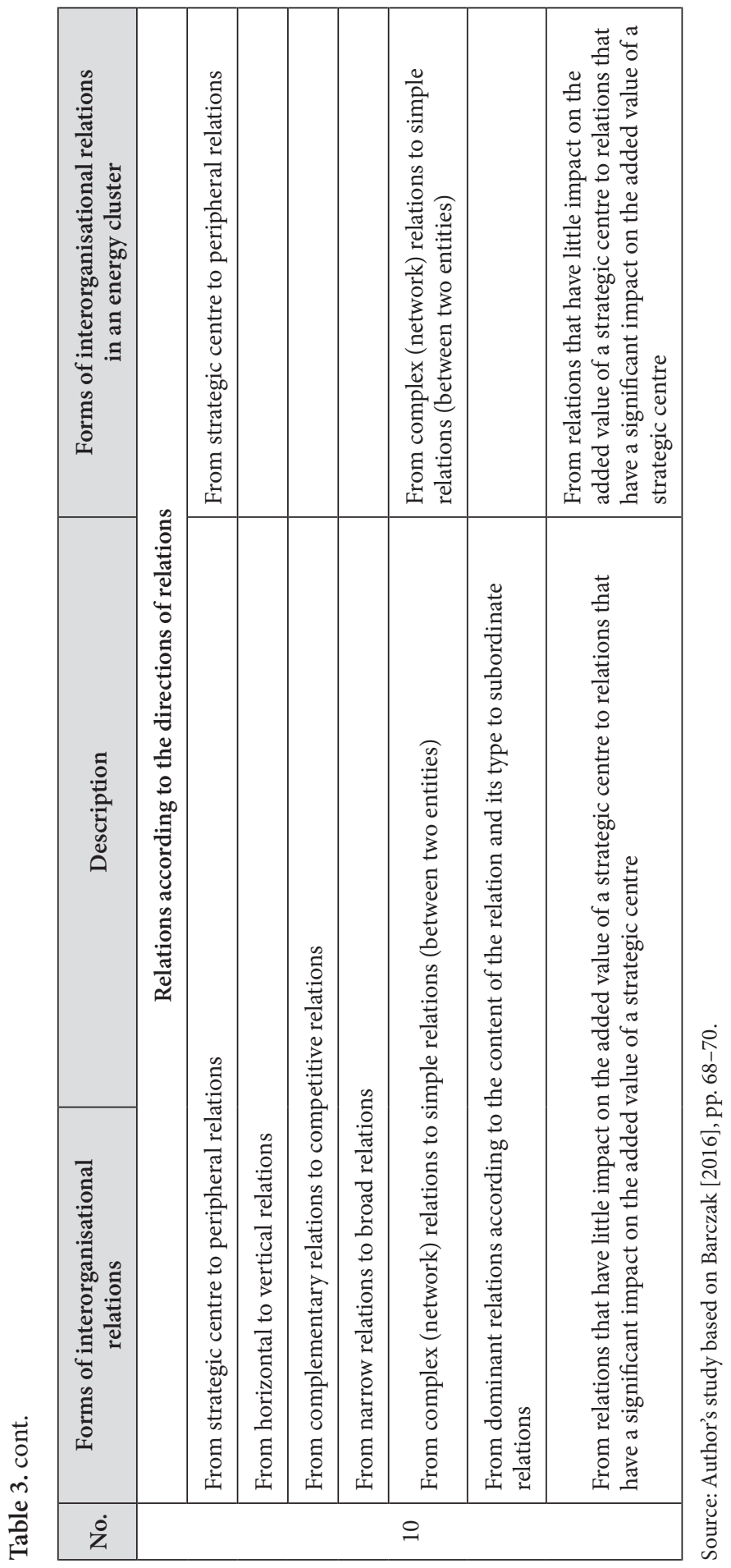




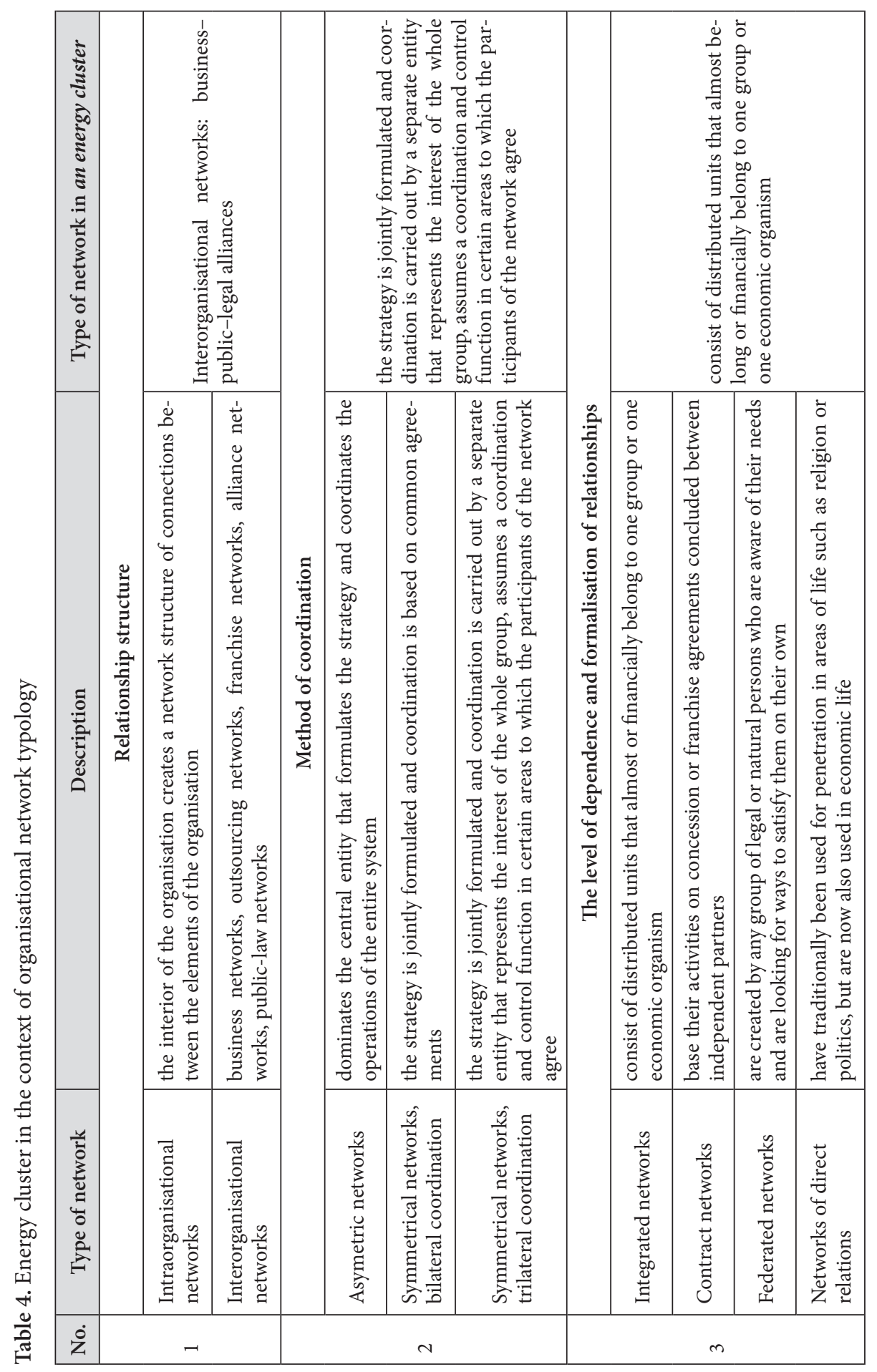




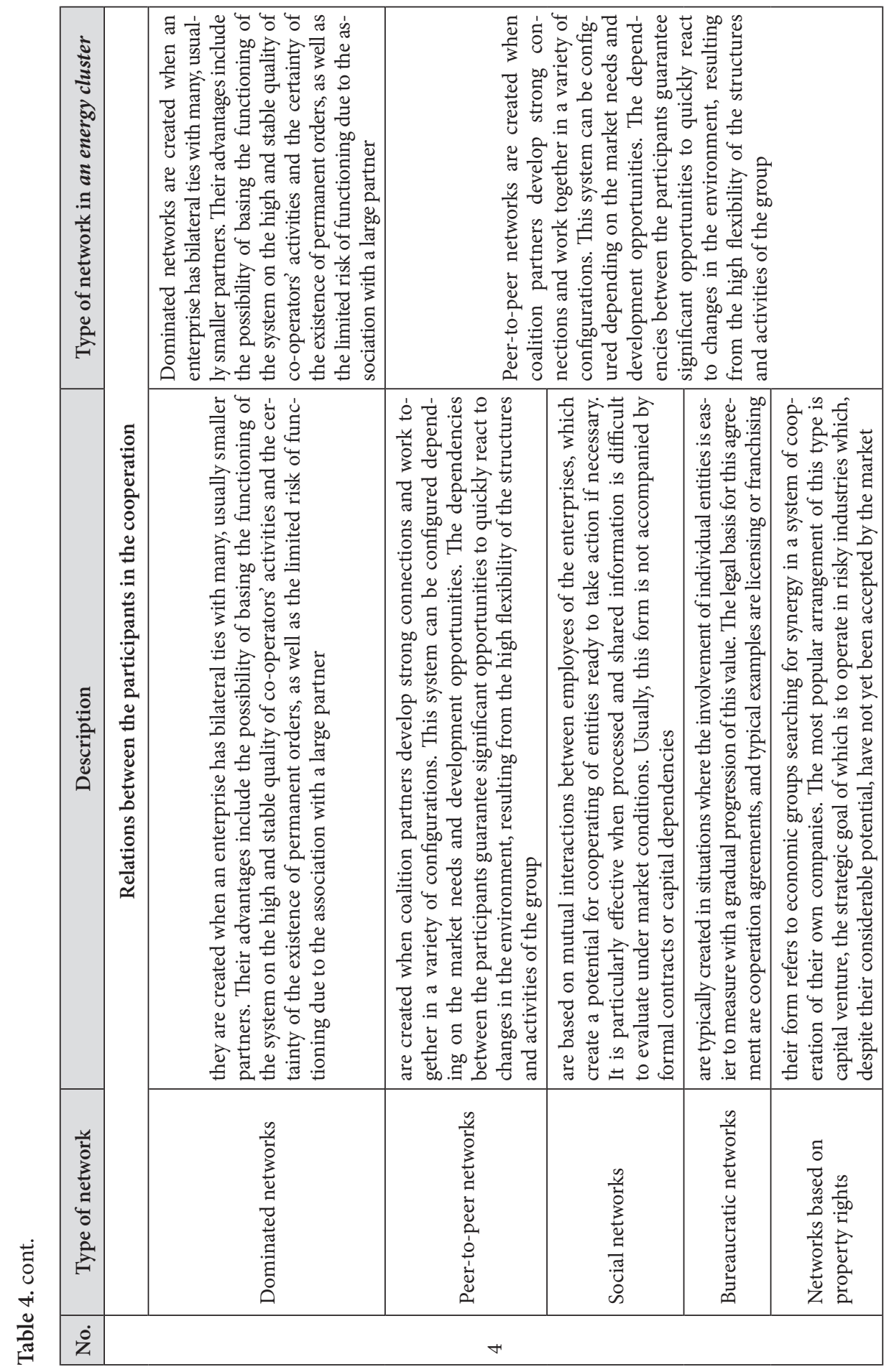




\begin{tabular}{|c|c|c|c|c|c|c|c|c|c|c|c|c|c|}
\hline & 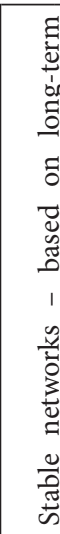 & 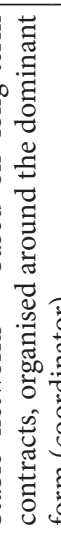 & & & 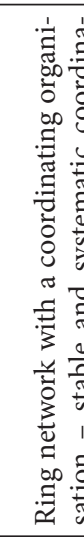 & 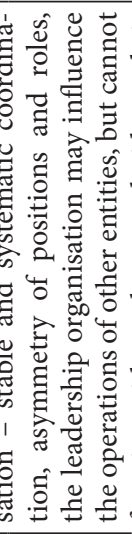 & 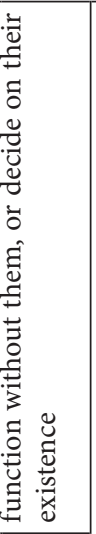 & & & 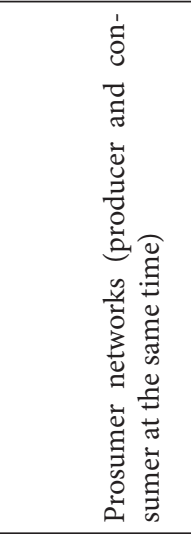 & & 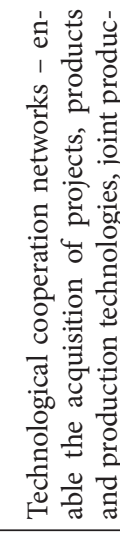 & 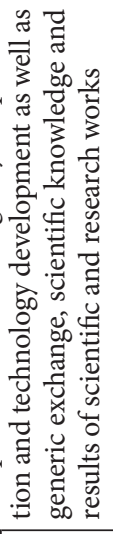 \\
\hline 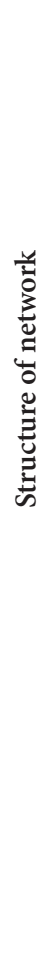 & 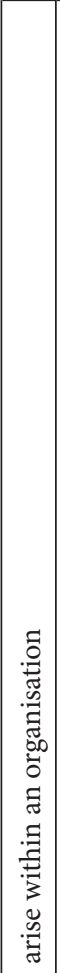 & 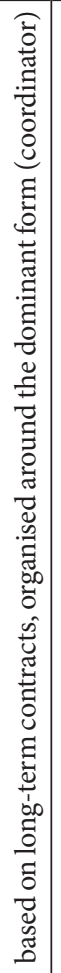 & 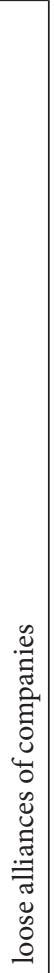 & 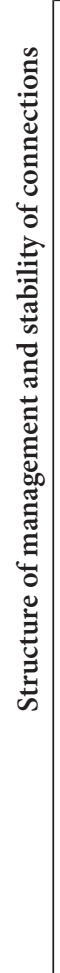 & 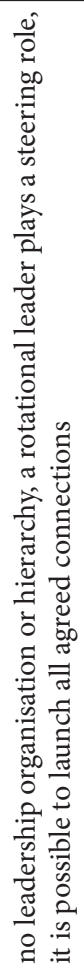 & 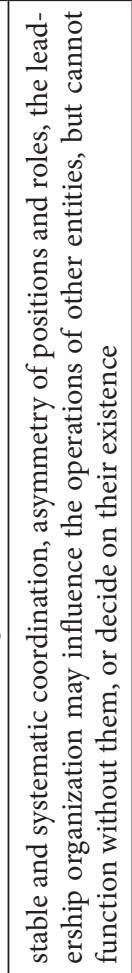 & 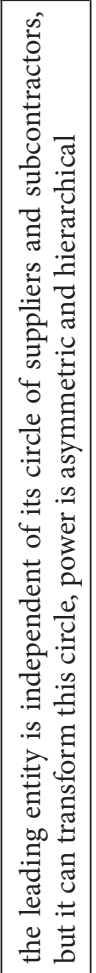 & 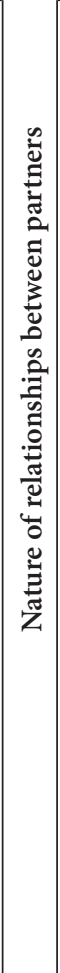 & 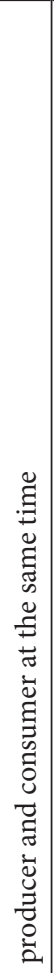 & 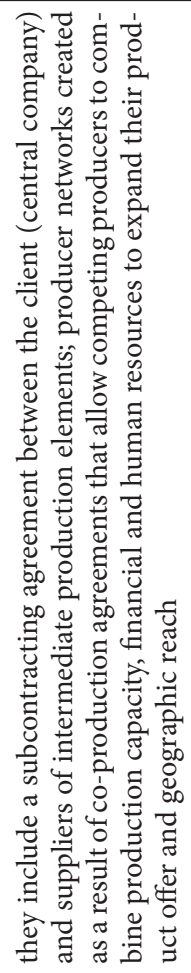 & 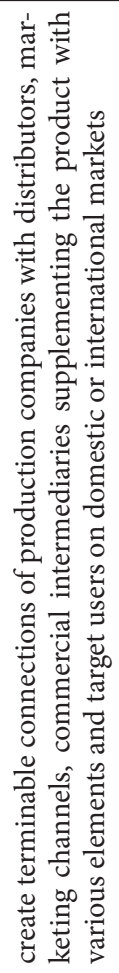 & 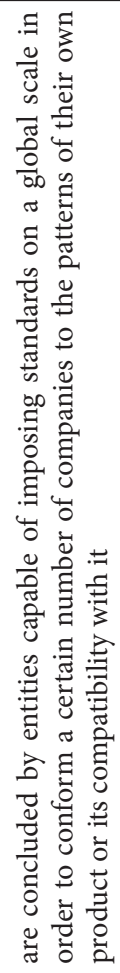 & 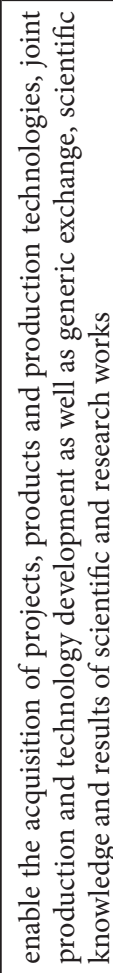 \\
\hline & 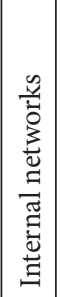 & 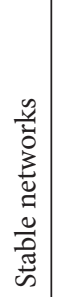 & 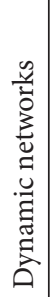 & & 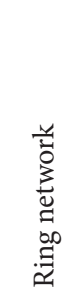 & 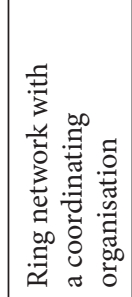 & 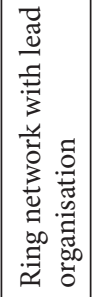 & & 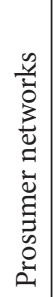 & 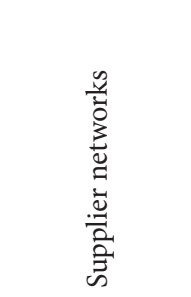 & 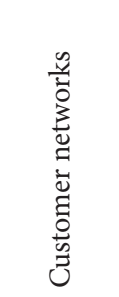 & 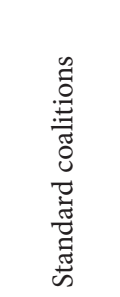 & 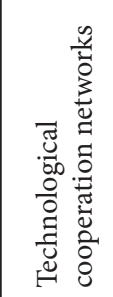 \\
\hline & ir & & & & & 6 & & & & & & & \\
\hline
\end{tabular}




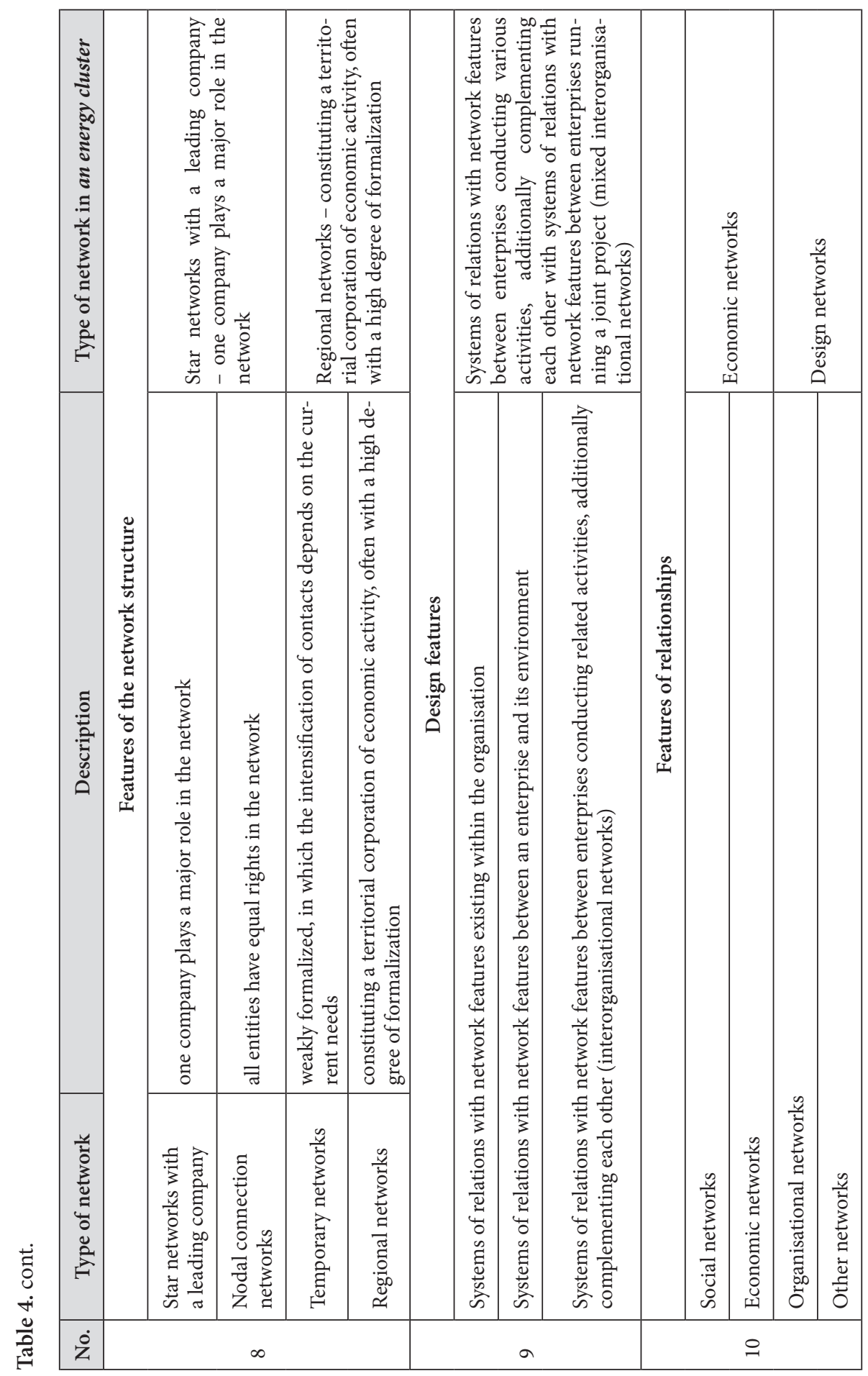




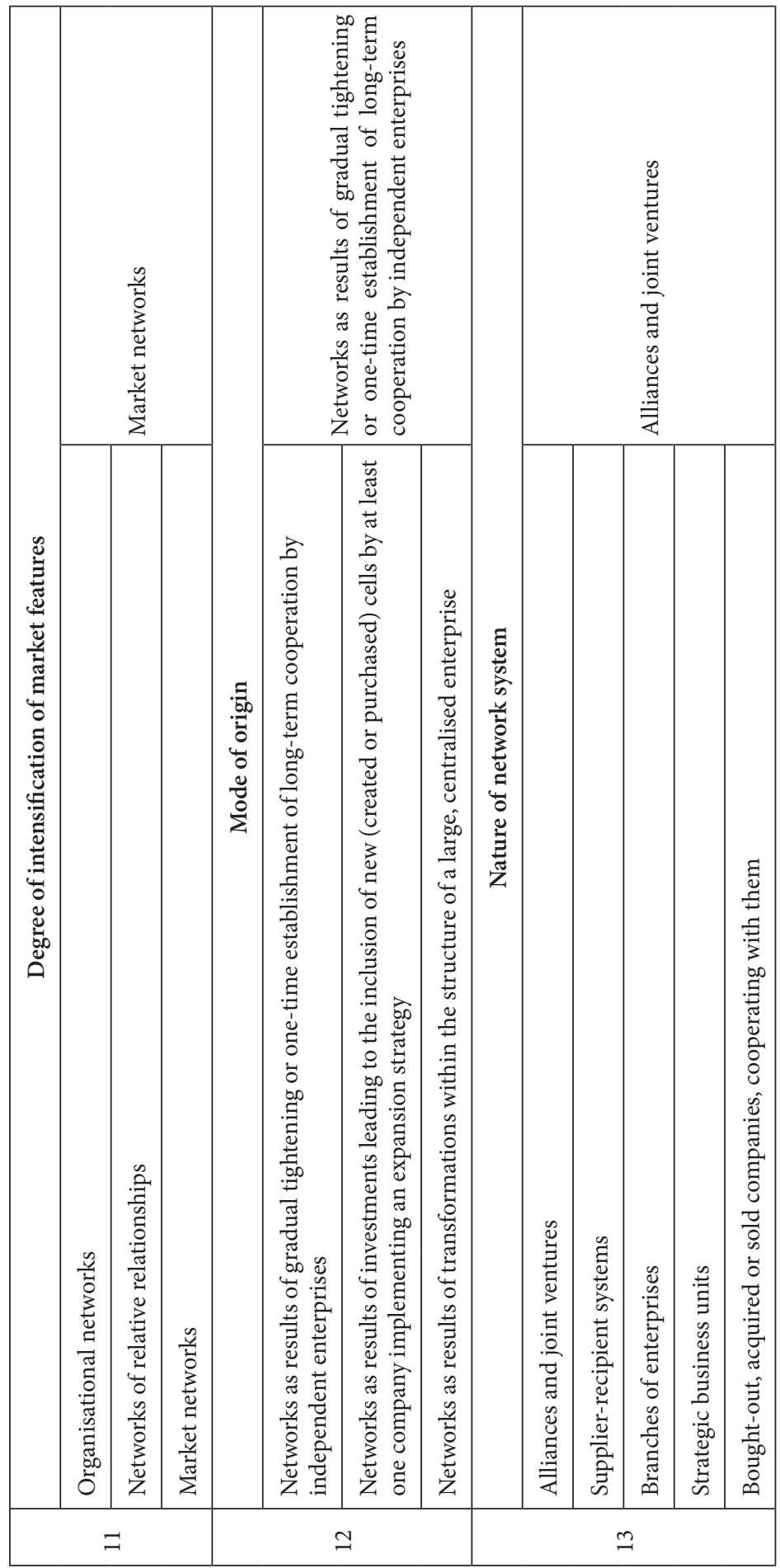




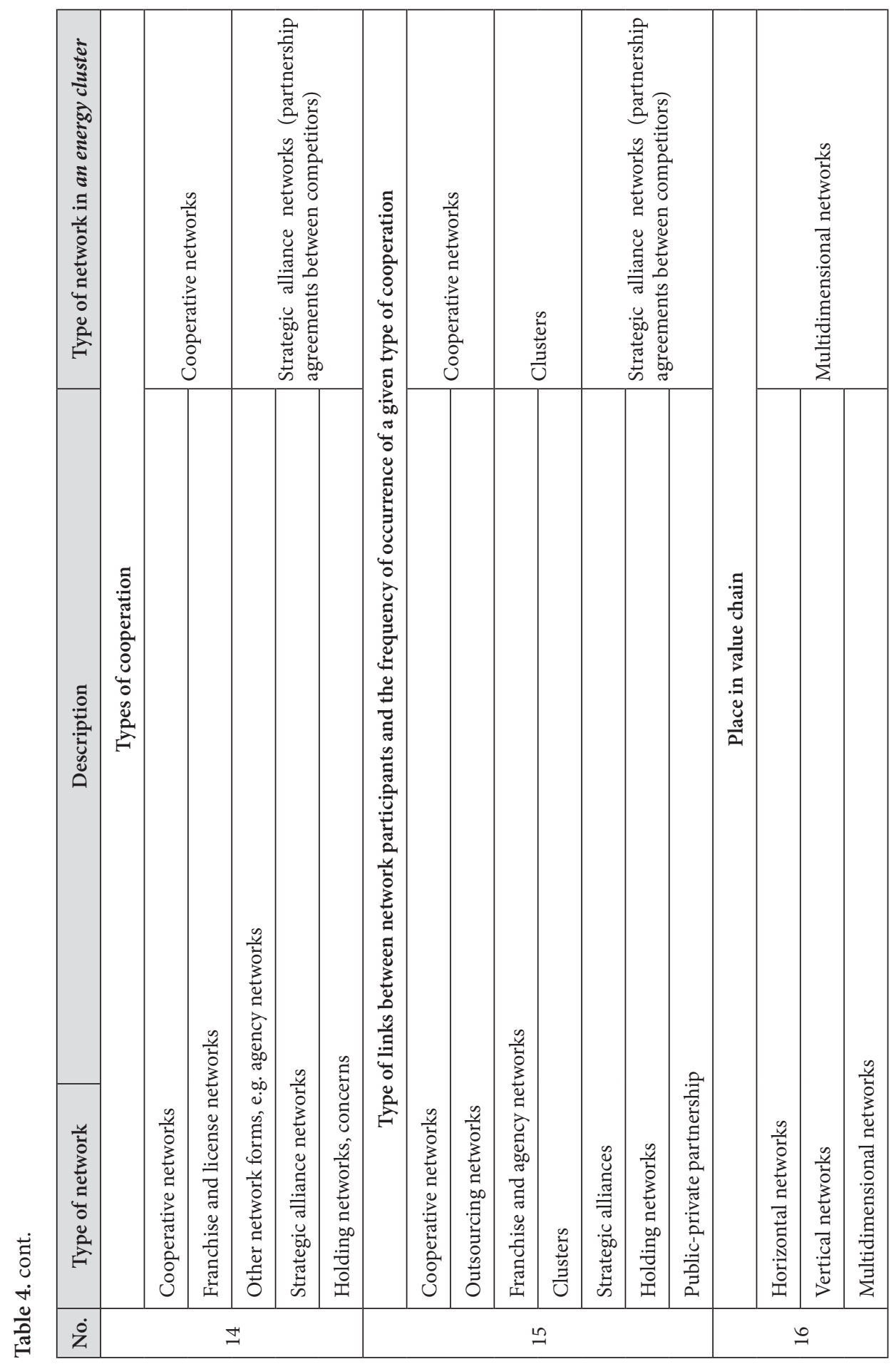




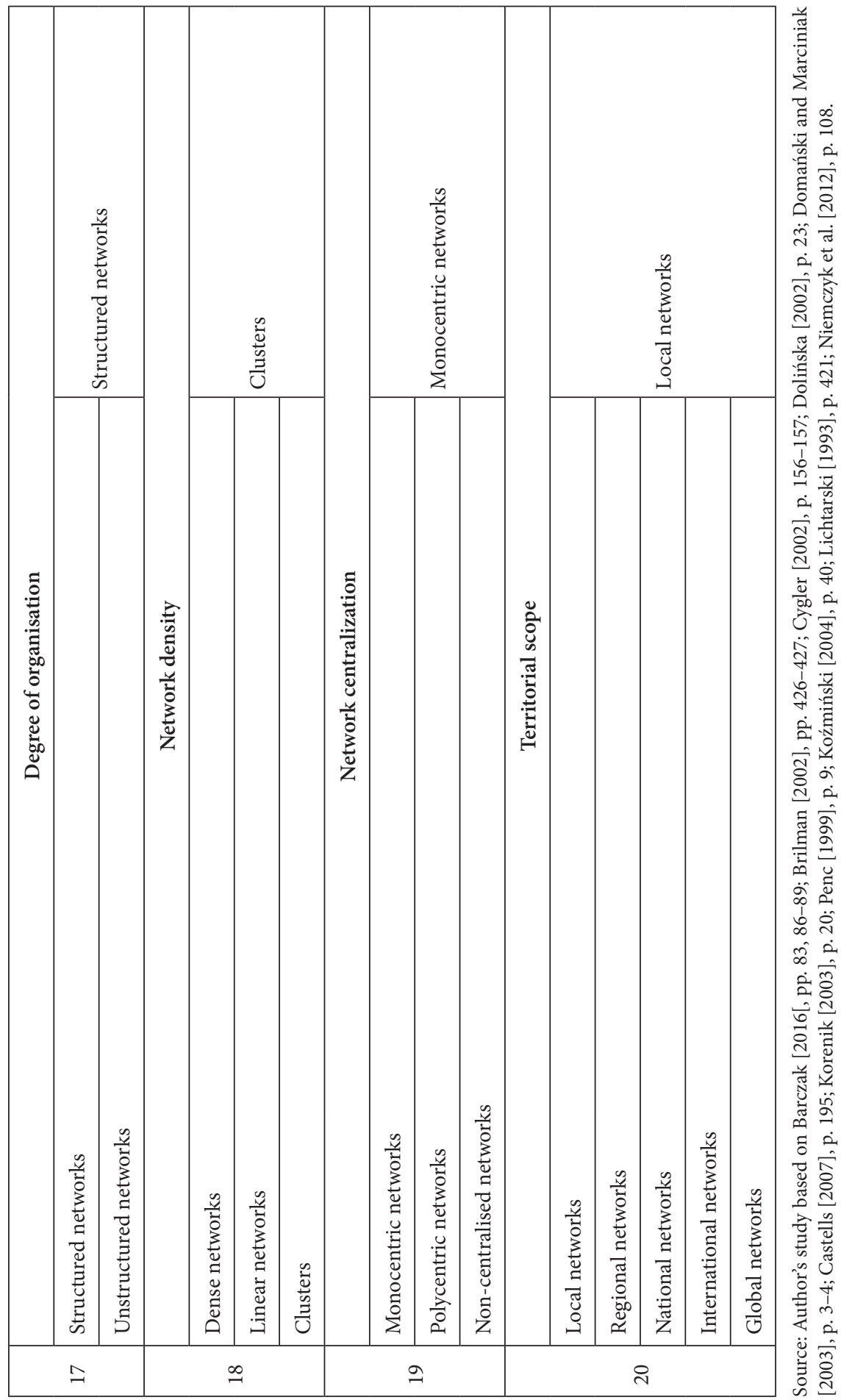


Table 5. Energy cluster as a form of company network - common features and differences

\begin{tabular}{|c|c|c|}
\hline Business networks & Porter cluster & Energy cluster \\
\hline \multicolumn{3}{|c|}{ Common features } \\
\hline \multicolumn{3}{|l|}{ loose connections } \\
\hline \multicolumn{3}{|l|}{ reciprocity of benefits } \\
\hline \multicolumn{3}{|l|}{ voluntary union } \\
\hline \multicolumn{3}{|l|}{ investing in building relationships } \\
\hline \multicolumn{3}{|l|}{ transfer of resources between units } \\
\hline \multicolumn{3}{|c|}{ creating and strengthening information channels } \\
\hline \multicolumn{3}{|c|}{ independence of individuals in economic and legal terms } \\
\hline \multicolumn{3}{|c|}{ interdependence of entities on resources controlled by other companies } \\
\hline \multicolumn{3}{|c|}{ Differences } \\
\hline no territorial restrictions & spatial concentration of entities & spatial concentration of entities \\
\hline cooperation & competition and cooperation & co-production and coopetition \\
\hline $\begin{array}{l}\text { implementation of own goals by } \\
\text { individual network entities }\end{array}$ & activation of a region & activation of the region \\
\hline \multirow[t]{2}{*}{ inward action } & $\begin{array}{l}\text { existence of an entrepreneurial } \\
\text { company }\end{array}$ & $\begin{array}{l}\text { existence of an entrepreneurial } \\
\text { company (coordinator) }\end{array}$ \\
\hline & outdoor operation & $\begin{array}{l}\text { inwards and outwards } \\
\text { operation }\end{array}$ \\
\hline
\end{tabular}

Source: Author's study based on: Skawińska and Zalewski [2009], p. 170; Santarek et al. [2005]; Rosińska [2005b]; Brodzicki and Szultka [2002].

\section{An attempt in characterisation and definition of an energy cluster}

Taking into account the above considerations, it is possible to start an initial assignment of an energy cluster against the background of network structures, which is illustrated in Figure 1.

Energy cluster, in effect of its situation in the scheme of network structures, is an interorganisational network, and a business-public-legal alliance, which can be treated as a specific 'economic office.' This corresponds to M.H. Bestem's statement that 'a cluster of companies is a collective company' [Best 2001, p. 81; Skawińska and Zalewski 2009 , p. 175]. The description of a network enterprise proposed by M. Castells also seems to be very accurate here:

'[It is] he organizational form built around business projects resulting from the cooperation between different components of different firms, networking among themselves for the duration of a given business project, and reconfiguring their 


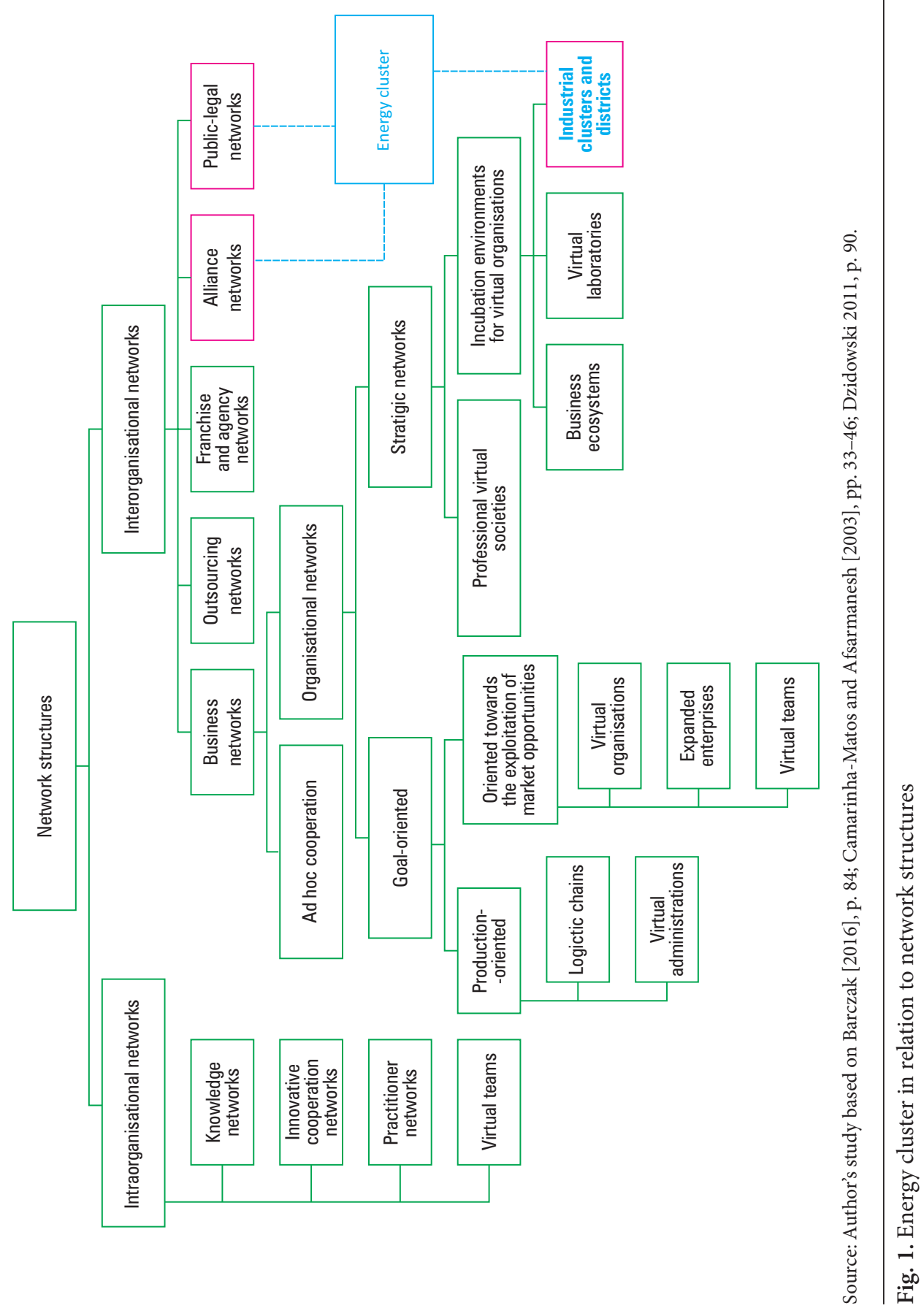


networks for the implementation of each project. [...] Thus, the network enterprise is neither a network of enterprises nor an intra-firm, networked organization. Rather, it is a lean agency of economic activity, built around specific business projects, which are enacted by networks of various composition and origin: the network is the enterprise. While the firm continues to be the unit of accumulation of capital, property rights (usually), and strategic management, business practice is performed by ad hoc networks. These networks have the flexibility and adaptability required by a global economy subjected to relentless technological innovation and stimulated by rapidly changing demand' [Castells 2001, pp. 80-81; Barney 2008, pp. 100-101].

This allows us to conclude that entities in an energy cluster, become a part of an industry, despite not belonging to it initially, by creating a network of strategic alliances. At the same time, they remain with their core business and therefore there is no competition in the implementation of the alliance. Therefore, for an energy cluster not competition, but rather energy security and ecology is the goal.

Summarising the above considerations and at the same time taking into account the importance of prosumers as producers and consumers and coopetition as cooperation within the same activities, and competition within other activities, the following definition of an energy cluster can be proposed:

Regional interorganisational network, which is a business-public-legal alliance, constituting a concentration of mutually related prosumers, cooperating in the implementation of a specific project, through ties independent of the type of basic operation; the entities work closely together, and one of them has predominant power (the coordinator).

\section{References}

Asheim B., Isaksen A. 2002. Regional Innovation Systems: The Integration of Local Sticky and Global Ubiquitous Knowledge. Journal of Technology Transfer, 2, 1.

Baker W.E., Faulkner R.R. 2002. Interorganizational Networks. In: The Blackwell Companion to Organizations. Ed. A.C. Baum. Blackwell Publishers Ltd., Oxford.

Barczak B. 2016. Koncepcja oceny efektywności struktur sieciowych. Wydawnictwo Uniwersytetu Ekonomicznego w Krakowie, Kraków.

Barney D. 2008. Społeczeństwo sieci. Wydawnictwo Sic!, Warszawa.

Becattini G. 1991. Italian Industrial Districts: Problems and Perspectives. International Studies of Management and Organization, 21, 1.

Becattini G., Bellandi M., De Propris L. 2009. Handbook of Industrial Districts. Edward Elgar Publishing, Cheltenham.

Bellandi M. 2007. Industrial Districts and Waves of Industrialization: A Rich and Contested Terrain. Italian Journal of Regional Science, 6, 2.

Bengtsson M., Kock S. 1999. Cooperation and Coopetition in Relationship between Competitors in Business Networks. Journal of Business \& Industrial Marketing, 14, 3.

Best M.H. 2001. The New Competitive Advantage. The Renewal of American Industry. Oxford University Press, Oxford.

Brilman J. 2002. Nowoczesne koncepcje i metody zarządzania. PWE, Warszawa. 
Brodzicki T., Szultka S. 2002. Koncepcja klastrów a konkurencyjność przedsiębiorstw. Organizacja i Kierowanie, 4 (110). Warszawa.

Camarinha-Matos L.M., Afsarmanesh H. 2003. A Roadmap for Strategic Research on Virtual Organizations. In: L.M. Camarinha-Matos, H. Afsarmanesh. Processes and Foundations for Virtual Organizations. Kluwer Academic Publishers, Boston.

Castells M. 2001. The Internet Galaxy: Reflections on the Internet, Business and Society. Oxford University Press (Polish edition: Galaktyka internetu. Rebis, Poznań 2003).

Castells M. 2007. Społeczeństwo sieci. PWN, Warszawa.

Cegle G., Dini M. 2015. SME Cluster and Network Development in Development Countries: The experience of UNIDO. UNIDO Private Sector of Development Branch Investment Promotion and Industrial Capacity Bouilding Division, Vienna 1999, p. 2: http://unido.org/fileadmi/user_media/Services/PSD/Clusters_and_Networks/publications/ceglie_dini.pdf

CLOE. 2014. What is a cluster? Regional Stekeholders. Cluster Linked Over Europe. http://www. clusterforum.org

Cooke P. 2002. Knowledge economies: Clusters, learning and cooperative advantage. Routledge, London.

Crouch C., Farrell H. 2001. Great Britain: Falling through the Holes in the Network Concept. In: C. Crouch. Local Production Systems in Europe: Rise or Demise? Oxforf University Press, Oxford.

Cygler J. 2002. Organizacje sieciowe jako forma współdziałania przedsiębiorstw. In: M. Romanowska, M. Trocki. Przedsiębiorstwo partnerskie. Difin, Warszawa.

Cygler J. 2007. Kooperencja - nowy typ relacji między konkurentami. Organizacja i Kierowanie, 2.

DeBresson C. 1996. Why innovative activities cluster. In: C. DeBresson. Economic Interdependence and Innovative Activity: An Input-Output Analysis. Edward Elgar, Cheltenham, UK, 149-164.

Delporte-Vermeiren D., Vervest P., Van Heck E. 2004. In Search of Margin for Business Networks: The European Patent Office. European Management Journal, 22, 2.

Dolińska M. 2002. Działalność organizacji wirtualnych w sieci powiązań. Organizacja i Kierowanie, $107,12$.

Domański R., Marciniak A. 2003. Sieciowe koncepcje gospodarki miast i regionów. CXII, KPZK, PAN, Warszawa.

Drelich-Skulska B., Jankowiak A.H., Mazurek S. 2014. Klastry jako nośnik innowacyjności przedsiębiorstw i regionów. Czy doświadczenia azjatyckie można wykorzystać w warunkach gospodarki polskiej? Wydawnictwo Uniwersytetu Ekonimicznego we Wrocławiu, Wrocław.

Drucker P. 1998. The New Organisation. Harvard Business Review, 1-2.

Dwojacki P., Nogalski B. 1998. Tworzenie struktur sieciowych jako wynik restrukturyzacji scentralizowanych przedsiębiorstw. Przegląd Organizacyjny, 4.

Dzidowski A. 2011. Ocena efektywności współpracy przedsiębiorstw w strukturach sieciowych. In: H. Brdulak, E. Duliniec, T. Gołębiowski. Współpraca w łańcuchach dostaw a konkurencyjność przedsiębiorstw i kooperujących sieci. Zeszyty Naukowe Kolegium Gospodarki Światowej, 32, Warszawa.

Enright M.J. 1996. Regional Cluster and Economic Development: A Research Agenda. In: U.H. Staber, N.V. Schaefer, B. Sharma. Business Networks: Prospects for Regional Development. Walter de Gruyter, Berlin.

ETCoI. 2015. European Trend Chart on Innovation. Thematic Report Cluster Policies, Covering Period up to March 2003. European Comission Enterprise Directorate General, p. 3. http:// www.cnel.gov.pt/document/cluster_policiesreport.pdf 
EU. 2003. Final report of the expert group on enterprise clusters and networks. European Commission - Enterprise Directorate General.

Feser E.J. 1998. Old and new theories of industry clusters. In: Clusters and Regional Specialisation: On Geography, Technology and Networks. Pion, London.

Gancarczyk M. 2012. Koncepcja sieci z perspektywy teorii kosztów transakcyjnych. Contemporary Management Quarterly, 3.

Glăvan B. 2008. Coordination failures, clusters theory and enterpreneurship: A critical view. The Quarterly Journal of Austrian Economics, 11(1).

Gorynia M., Jankowska B. 2007. Koncepcja klastrów jako sposób regulacji zachowań gospodarczych. Ekonomista, 3.

Gorynia M., Jankowska B. 2008. Klastry a międzynarodowa konkurencyjność i internacjonalizacja przedsiębiorstwa. Difin, Warszawa.

Gorynia M., Jankowska B. 2009. Kooperacja w klastrze jako instytucja gospodarki rynkowej na przykładzie trzech klastrów z Wielkopolski. Prace Naukowe Uniwersytetu Ekonomicznego we Wrocławiu, 74. Ekonomia 3. Mikroekonomia i ekonomia instytucjonalna. Wydawnictwo Uniwersytetu Ekonomicznego we Wrocławiu, Wrocław.

GUS. 2005. Działalność innowacyjna przedsiębiorstw w sektorze usług w latach 2110-2003. GUS, Warszawa.

Hamphrey J., Schmitz H. 1995. Principles for Promoting Clusters ant Networks of SMEs. UNIDO, Vienna.

Hatch M.J. 2002. Teoria organizacji. Wydawnictwo Naukowe PWN, Warszawa.

Higgins K.L., Maciariello J.A. 2004. Leading Complex Collaboration in Network Organizations. A Multidisciplinary Approach. Advances in Interdisciplinary Studies of Work Teams, 10.

Hołub-Iwan J., Wielec Ł. 2014. Opracowanie systemu wyboru Krajowych Klastrów Kluczowych (Raport I „Charakterystyka krajowego klastra kluczowego w oparciu o analizę źródeł wtórnych". PARP, Warszawa.

Jacobs D., de Man A.P. 1996. Clusters, industrial policy and firm strategy: A menu approach. Technology Analysis and Strategic Management, 8(4).

Kazojć K. 2016. Model transferu technologii w klastrach morskich w Polsce. CeDeWu, Warszawa.

Kaźmierski J. 2012. Rozwój i zarządzanie strukturami. Wydawnictwo Uniwersytetu Łódzkiego, Łódź.

Knop L. 2013. Zarządzanie klastrem. Koncepcje, strategie, modele. Wyd.Politechniki Śląskiej, Gliwice.

Korenik S. 2003. Dysproporcje w rozwoju regionów Polski - wybrane aspekty. Wydawnictwo Akademii Ekonimicznej we Wrocławiu, Wrocław.

Kowalski A.M. 2010. Kooperacja w ramach klastrów jako czynnik zwiększania innowacyjności i konkurencyjności regionów. Gospodarka Narodowa, 5-6.

Koźmiński A.K. 2004. Zarządzanie w warunkach niepewności: Podręcznik dla zaawansowanych. PWN, Warszawa.

Lichtarski J. 1993. Współdziałanie gospodarcze przedsiębiorstw. PWE, Warszawa.

Lis A.M., Lis A. 2014. Zarządzanie kapitałami w klastrach. Kapitał społeczny, kulturowy, ekonomiczny i symboliczny w strukturach klastrowych. Difin, Warszawa.

Lundvall B.A., Borras S. 1997. The Globalisisng Learning Economy: Implications for Innovation Policy. Brussels: Report for DG XII, Comission of the European Union.

Łobos K. 2005. Struktury sieciowe. In: R. Krupski. Zarządzanie przedsiębiorstwem w turbulentnym otoczeniu. PWE, Warszawa.

Marshall A. 1925. Zasady ekonomiki, t. 1. Wydawnictwo M. Arcta, Warszawa. 
Martin R., Sunley P. 2003. Deconstructing clusters: chaotic concept or policy panacea? Journal of Economic Geography, 3(1).

Maskell O., Kebir L. 2005. What Qualifies as a Cluster Theory. DRUID, Working Paper, nr 05-09.

Maskell P., Kebir L. 2014. What Qualifies as a Cluster Theory? DRUID Working Paper No. 05-09. http://www3.druid.dk/wp/20050009.pdf

Matusiak K.B. 2005. Innowacje i transfer technologii. Słownik pojęć. PARP, Warszawa.

McDonald F., Beluss F. 2002. Industrial Districts: A State of the Art Review. Project West-East ID Industrial Districts Re-Location Processes: Identyfying Policies in the Perspective of the European Union Enlargement. Instituto G.Tagliacarne, Rome.

Ministerstwo Gospodarki. 2006. Rozporządzenie Ministra Gospodarki z dnia 2 grudnia 2006 roku w sprawie udzielania przez Polską Agencję Rozwoju Przedsiębiorczości pomocy finansowej niezwiązanej z programami operacyjnymi.

Ministerstwo Gospodarki. 2008. Rozporządzenie Ministra Gospodarki z dnia 1 września 2008 roku (Dz.U. 161, poz.1003).

Morosini P. 2004. Industrial Clusters, Knowledge Integration and Performance. World Development, 32, 2.

Mukherjee A.S. 2009. Leading the Networked Organizations. Leader to Leader, 52.

Munnich L.W. 1999. Industry Clusters: An Economic Development Strategy for Minnesota Preliminary Report. University of Minnesota Service.

Niemczyk J., Stańczyk-Hugiet E., Jasiński B. 2012. Sieci międzyorganizacyjne. Współczesne wyzwania dla teorii i praktyki zarządzania. Wydawnictwo C.H. Beck, Warszawa.

OECD. 2004. Clusters in Transition Economies (draft). OECD LEED Programme, Paris.

Olesiński Z. 2010. Zarządzanie relacjami międzyorganizacyjnymi. Wydawnictwo C.H. Beck, Warszawa.

Padmore T., Gibson H. 1998. Modeling regional innovation and competitiveness. In: J. de la Mothe, G. Paquet. Local and Regional Systems of Innovation. Kluwer Academic Publishers. Boston, Dordrecht, London.

PARP. 2017. http://www.pi.gov.pl/klastry/chapter_95882.asp; http://www.pi.gov.pl/PARP/chapter_96055.asp?soid=F7B02F71548C419C99DF4BD6CE9A412A

PARP. 2017a. Standardy zarządzania klastrem. http://www.pi.gov.pl/PARPFiles/file/klastry/ PARP_Standardy_zarzadzania_klastrem_2016.pdf

Penc J. 1999. Strategie zarządzania. Placet, Warszawa.

Perechuda K. 2005. Dyfuzja wiedzy w przedsiębiorstwie sieciowym. Wizualizacja i kompozycja. Wydawnictwo Akademii Ekonomicznej we Wrocławiu, Wrocław.

Phillips R.A. 2010. Ethics and Network Organizations. Business Ethics Quarterly, 3.

Pilarska C. 2013. Klastry. Doświadczenia Polski i innych krajów Unii Europejskiej. Wydawnictwo Uniwersytetu Ekonomicznego w Krakowie, Kraków.

Pitelis C., Sugden R., Wilson J.R. 2006. Cluster and Globalisation. The Development of Urban and Regional Economies. Edward Edgar, Northhampton.

Porter M.E. 1998. On Competition. Harvard Business School Press, Boston.

Porter M.E. 2000. Location, Competition and Economic Development: Local Clusters in the Global Economy. Economic Development Quarterly, 14(1).

Porter M.E. 2001. Porter o konkurencji. Wyd. PWE, Warszawa.

Rabelotti R. 1995. Is There an Industrial District Model? Footwear Districts in Italy and Mexico Compared. World Developement, 23(1), 29-41.

Roelandt T.J., den Hertog P. 1999. Cluster Analysis and Cluster-Based-Policy Making: The State of the Art. In: Boosting Innovation: The Cluster Approach, Regional Clusters in Europe. OECD, Paris. 
Rosenfeld S.A. 1996. Overachievers: Business Clusters that Work. Prospects for Regional Development. Regional Technology Strategies. Inc. Carborro NC.

Rosenfeld S.A. 1997. Bringing Business Cluster sinto Mainstream of Economic Development. European Planning Studies, 5, 1.

Rosińska M. 2005a. Podejście sieciowe jako element koncepcji poprawy konkurencyjności przedsiębiorstw we współczesnej gospodarce (na przykładzie strategii rozwoju przedsiębiorczości Unii Europejskiej). In: Ed. J. Bilski. Polska na rynku Wspólnoty Europejskiej. Gospodarka światowa na progu XXI wieku, t. 2. Łódzkie Towarzystwo Naukowe, Łódź.

Rosińska M. 2005b. Sieci biznesowe jako forma integracji celu optymalizacji warunków działania na rynku globalnym - ujęcie teoretyczne. In: Ed. E. Najlepszy. Biznes międzynarodowy a internacjonalizacja gospodarki narodowej. AE, Poznań.

Santarek K., Kosieradzka A., Rafalski R. 2005. Struktury sieciowe przedsiębiorstw. Wyd. Politechniki Warszawskiej, Warszawa.

Simmie J., Sennett J. 1999. Innovation in the London Metropolitan Region. In: D. Hart. Innovative Clusters and Competitive Cities in the UK and Europe. Oxford Brookes School of Planning, Working Paper No. 182.

Skawińska E., Zalewski R.I. 2009. Klastry biznesowe w rozwoju konkurencyjności i innowacyjności regionów. Świat - Europa - Polska. Polskie Wydawnictwo Ekonomiczne, Warszawa.

Söllvell Ö. 2009. Clusters - Balancing Evolutionary and Constructive Forces. Ivory Tower Publishers, Stockholm.

Sproull L., Kiesler S. 1992. Connections: New Ways of Working in the Networked Organization. Long Range Planning, 2.

Steinle C., Schiele H. 2002. When do industries cluster?: A proposal on how to assess an industry's propensity to concentrate at a single region or nation. Research Policy, 31 (6), 849-858.

Strategor. 2001. Zarządzanie firmą. Strategie, struktury, decyzje, tożsamość. PWE, Warszawa.

Swann P., Prevezer M. 1996. A comparison of the dynamics of industrial clustering in computing and biotechnology. Research Policy, 25(7), 1139-1157.

Swann P., Prevezer M. 1998. A Comparson of the Dynamics of Industrial Clustering in Computing and Biotechnology. Oxford University Press.

Sydow J. 1999. Mitbestimmung in Unternehmungsnetzwerken - Eine betriebswirtschaftliche Analyse. In: Eds: B. Frick, W. Streeck, N. Kluge. Die wir Folgen der Mitbestimmungtschaftlichen. Campus, Frankfurt, New York.

Thorelli H.B. 1986. Networks: between Markets and Hierarchies. Strategic Management Jouran, 7. UNIDO. 2001. Developement of Clusters and Networks of SMEs. UNIDO, Vienna.

Ustawa OZE o odnawialnych źródłach energii. Dz.U. 2016, poz. 925, 1579 (luty 20, 2015).

Van den Berg L., Braun E., Van Winden W. 2001. Growth Clusters in European Cities: An Integral Approach. Urban Studies, 38, 1.

Van Dijk M.P., Sverrisson Á. 2003. Enterprise clusters in developing countries: mechanism of transition and stagnation. Enterpreneurship \& Regional Development, 15(3).

Wiśniewska J., Janasz K. 2015. Innowacje i procesy transferu technologii w strategicznym zarządzaniu organizacjami. Difin, Warszawa.

Dr Joanna Gronkowska

Poviat Treasurer, Nowy Targ Poviat

e-mail: gronkowska.joanna@gmail.com 